\title{
The next step: mechanisms driving adrenocortical carcinoma metastasis
}

\author{
Enzo Lalli1,2,3,4 and Michaela Luconi ${ }^{5}$ \\ 1Université Côte d'Azur, Valbonne, France \\ 2CNRS UMR7275, Valbonne, France \\ ${ }^{3}$ NEOGENEX CNRS International Associated Laboratory, Valbonne, France \\ 4 Institut de Pharmacologie Moléculaire et Cellulaire, Valbonne, France \\ ${ }^{5}$ Department of Experimental and Clinical Biomedical Sciences 'Mario Serio', University of Florence, Florence, Italy
}

Correspondence should be addressed to E Lalli or M Luconi: ninino@ipmc.cnrs.fr or michaela.luconi@unifi.it

\begin{abstract}
Endocrine tumors have the peculiarity to become clinically evident not only due to symptoms related to space occupation by the growing lesion, similarly to most other tumors, but also, and most often, because of their specific hormonal secretion, which significantly contributes to their pathological burden. Malignant endocrine tumors, in addition, have the ability to produce distant metastases. Here, we critically review the current knowledge about mechanisms and biomarkers characterizing the metastatic process in adrenocortical carcinoma (ACC), a rare endocrine malignancy with a high risk of relapse and metastatization even when the primary tumor is diagnosed and surgically removed at an early stage. We highlight perspectives of future research in the domain and possible new therapeutic avenues based on targeting factors having an important role in the metastatic process of ACC.
\end{abstract}

\author{
Key Words \\ - adrenocortical carcinoma \\ - metastasis \\ - biomarkers \\ - liquid biopsy
}

\section{An introduction to the metastatic process}

\section{Primary and metastatic cancer}

Endocrine tumors have the peculiarity to become clinically evident not only due to symptoms related to space occupation by the growing lesion, similarly to most other tumors, but also, and most often, because of their specific hormonal secretion, which significantly contributes to their pathological burden. Malignant endocrine tumors, in addition, have the ability to produce distant metastases. Metastasis is the result of the dissemination through the bloodstream of an aggressive tumor beyond its organ of origin, resulting in colonization of other tissues and organs. This is a complex multistep process that is the eventual cause of the overwhelming majority of deaths due to cancer (Valastyan \& Weinberg 2011, Vanharanta \& Massagué 2013). Therefore, it is quite paradoxical that metastases stem from an extremely inefficient process for which several sequentially occurring events are required, similar to an obstacle race: from the initial local invasion of tumor cells through the surrounding extracellular matrix to the subsequent steps of entering the microcirculation (intravasation), being transported through the vasculature, arresting at distant organ sites, migrating into the tissue parenchyma (extravasation), initially surviving in the new, potentially hostile, environment forming micrometastases and finally growing into clinically detactable macroscopic neoplastic masses. All this while being forced to continuously decoy the surveillance of the immune system and to play a tugof-war game with the local microenvironment, which can 
act in favor or against the metastatic growth (Valastyan \& Weinberg 2011, Lambert et al. 2017). It has been calculated that the rate of attrition through all these steps exceeds $99 \%$ of the initial pool of cells entering the first steps of the metastatic process (Luzzi et al. 1998, Valastyan \& Weinberg 2011). The complexity of the metastatic process and the small chance for a single metastatic event to reach completion probably accounts for the often long interval between the diagnosis of the primary tumor and of the metastases, even if, unfortunately, notable exceptions are represented by lung and pancreatic adenocarcinomas.

\section{Molecular determinants and markers of the first steps in the metastatic process}

Most of the knowledge about the molecular mechanisms driving metastatization and biomarkers of metastasis derives from the study of carcinomas, which are derived from epithelia, with breast cancer, colon cancer and melanoma often representing the paradigms. Concerning the initial steps of the metastatic process, several studies have revealed the importance of collective invasion by cohesive multicellular units as well as of individual tumor cell invasion in its amoeboid or mesenchymal types (Clark \& Vignjevic 2015). In carcinomas, the importance of epithelial-to-mesenchymal transition (EMT) is well recognized as an important mechanism to drive metastatic invasion (Lambert et al. 2017, Liao \& Yang 2017). Briefly, EMT consists in a process of loss of adherens and tight junctions in epithelial cells, characterized by downregulation of E-cadherin expression and accompanied by a loss in cell polarity. All these events favor acquisition of a mesenchymal phenotype making epithelial tumor cells more prone to migration. EMT programs, which are physiologically very important during embryonic development, are orchestrated by a core of coordinately regulated transcription factors and miRNAs (Nieto et al. 2016). However, in the case of endocrine tumors, it is presently uncertain whether expression of classical EMT markers also indicates tedency to local invasion because of their distinct embryonic origin compared to epithelial tumors (see below). Important roles in the initiating steps of the metastatic process are also played by factors involved in extracellular matrix degradation, like matrix metalloproteinases (MMPs), by stromal cells in the local microenvironment and by tumor induction of local inflammation and angiogenesis (Valastyan \& Weinberg 2011, Vanharanta \& Massagué 2013). In addition, the up- and downregulation of specific sets of miRNAs have been associated with metastatization in several types of endocrine cancers through a variety of mechanisms (Lima et al. 2017).

\section{Metastasis in adrenocortical carcinoma (ACC): do paradigms apply?}

ACC is a rare endocrine malignancy with a high risk of relapse and metastatization even when the primary tumor is diagnosed and surgically removed at an early stage (Else et al. 2014, Creemers et al. 2016). Current treatments for ACC have only a limited efficacy when disease is at an advanced stage and rely upon use of the adrenolytic agent mitotane (Terzolo et al. 2007) and of combination chemotherapy in patients with progressive disease (Fassnacht et al. 2012). Classically, malignancy of adrenocortical tumors (ACTs) has been assessed based on evaluation of specific histopathological parameters. Recent molecular and genomic studies have allowed to make considerable advances in the identification of the biological bases of ACC and of the aggressive behavior of a subset of histologically malignant tumors.

\section{Histopathological evaluation of malignancy in ACT:} around and beyond the Weiss score

For adrenal tumors, the pathological diagnosis of malignancy cannot rely on single morphological parameters but rather on the presence of a combination of multiple features each one indicative, even if not sufficient by itself, of an aggressive behavior. The most widely used approach in routine pathological practice is the scoring method by Weiss, which takes into account an ensemble of nine different histopathological features related to tumor structure (presence of necrosis, diffuse architecture, clear cells $<25 \%$ ), tumor cell properties (nuclear atypia, mitotic index $>5 / 50$ high-power fields, atypical mitoses) and tumor invasion (sinusoidal, venous and capsular invasion), respectively (Weiss 1984). A binary score of either 0 (absence) or 1 (presence) is attributed to each parameter. A given tumor is usually considered malignant when its cumulative score is equal to or higher than 3 taking into account all nine parameters. Suggestions for modifications of the Weiss scoring system have been given by Aubert and coauthors, who decreased the number of criteria to five and attributed higher weight to the number of mitoses and to a percentage of clear cells $<25 \%$ (Aubert et al. 2002). While the Weiss score is very useful as a general indicator of malignancy in clinical practice, it may have a limited value as a prognostic 
indicator in individual patients, especially in cases with borderline features (up to $10 \%$ of cases according to Papotti et al. (2011)), in children (Wieneke et al. 2003) and in histological subtypes of ACT as the oncocytic, myxoid and sarcomatoid tumors (Papotti et al. 2011). For these reasons, a new scoring system (Helsinki score) was recently introduced, which is based on the combined evaluation of morphological parameters (necrosis and mitotic index $>5 / 50$ high-power fields) and of the Ki67 labeling index (LI) (see below). This system was shown to be able to predict the metastatic potential of ACC with very high sensitivity and specificity (Pennanen $e t$ al. 2015). Another very recent study extended and confirmed the prognostic validity of the Helsinki score on a larger series of ACC cases (Duregon et al. 2017).

Another independent simplified diagnostic algorithm has been proposed for ACT (Volante et al. 2009) and further validated (Duregon et al. 2013a). This method takes into account the integrity of the reticulin network in the tumor, as visualized by silver-based histochemical staining, in ACT. Disruption of that network plus the presence of at least one of the three additional histopathological parameters (mitotic index $>5 / 50$ highpower fields, necrosis and vascular invasion) showed $100 \%$ sensitivity and specificity to recognize malignant tumors, as assessed using the Weiss system.

\section{Immunohistochemical markers improve prognostic assessment in ACC}

The most common marker used in clinical pathology is the Ki67 LI. Ki67 is a sensitive marker of the proliferative compartment in a cell population. The MIB1 antihuman Ki67 monoclonal antibody labels cell nuclei in phases of the cell cycle other than $\mathrm{G}_{0}$ (Gerdes et al. 1983). The Ki67 protein, encoded by the MKI67 gene, has a direct role in the mitotic process (Cuylen et al. 2016). Many studies have demonstrated the prognostic power of the Ki67 LI in different ACC series (McNicol et al. 1997, Terzolo et al. 2001, Morimoto et al. 2008, Duregon et al. 2014a) (Table 1). A recent large multicentric ENS@T study has shown that the KI67 LI is a very reliable parameter to predict disease recurrence (disease-free survival, DFS) and overall survival (OS) in ACC patients after complete tumor resection (Beuschlein et al. 2015). Furthermore, Ki67 LI integration with morphological parameters in the newly introduced Helsinki score makes it to outperform the Weiss system as a prognostic indicator in ACC (see above) (Pennanen et al. 2015, Duregon et al. 2017). However, a limitation of the Ki67 LI consists in difficulties in its standardization and reproducibility when applied to many tumor types, including ACC (Papathomas et al. 2016). These data indicate that other markers are needed to complement the Ki67 LI in the assessment of malignancy in ACC. So far, a substantial number of immunohistochemical markers have been shown to have a prognostic value in ACC:

- genomic studies (see below) have shown that in ACC, the Wnt pathway is the most frequently altered molecular pathway by gene mutations causing constitutive activation (Assié et al. 2014, Juhlin et al. 2015, Zheng et al. 2016). Canonical Wnt signaling regulates the translocation of the membrane protein beta-catenin to the nucleus, where it controls key gene expression programs through interaction with Tcf/Lef and other transcription factors. In many types of cancer, the gene encoding beta-catenin (CTNNB1) is mutated in those nucleotides that encode phosphorylation sites targeting the protein for distruction (El Wakil \& Lalli 2011). Tissier and coworkers first reported the presence of activating CTNNB1 mutations both in benign and malignant ACTs (Tissier et al. 2005). Further studies showed that in ACC, CTNNB1 and TP53 mutations, which are both associated with aggressive disease, are in large part mutually exclusive (Ragazzon et al. 2010). Beta-catenin nuclear staining is associated with shorter DFS and OS in ACC (Gaujoux et al. 2011). The important role of activated beta-catenin in driving ACC cell proliferation and maintaining viability was shown by studies using pharmacological inhibitors (Doghman et al. 2009) and RNA interference in vitro and in mouse H295R xenografts (Gaujoux et al. 2013, Salomon et al. 2015). In the study of Salomon and coworkers, CTNNB1 knockdown reportedly induced the reversal of 'EMT' in H295R cells, monitored through the expression of the putative markers vimentin, $\mathrm{N}$-cadherin and Slug. However, the mesodermal embryologic origin of the adrenal cortex makes ACT cells different from epithelial cells, for which the EMT process has been defined and demonstrated to play an important role in metastatic dissemination. In fact, in contrast to epithelial cells, mesoderm-derived tissues such as the adrenal cortex constitutively express vimentin as the characteristic intermediate filament, while $\mathrm{N}$-cadherin was reported to be downregulated in ACC compared to adrenocortical adenomas (ACAs) (KhorramManesh et al. 2002). In mouse models, constitutive adrenocortical beta-catenin activation, obtained using different transgenic strategies, leads to tumorigenesis 
Table 1 Immunohistochemical prognostic markers in ACC.

\begin{tabular}{|c|c|c|c|c|}
\hline Marker & Biological pathways & $\begin{array}{l}\text { Number of patients } \\
\text { studied }\end{array}$ & Outcome & References \\
\hline \multirow[t]{6}{*}{ Ki67 } & \multirow[t]{6}{*}{ Cell proliferation } & 40 & $\begin{array}{l}\text { Expression }>3 \% \text { associated } \\
\text { with shorter DFS }\end{array}$ & McNicol et al. (1997) \\
\hline & & 11 & $\begin{array}{l}\text { Inverse correlation between } \\
\text { Ki67 LI and OS }\end{array}$ & Terzolo et al. (2001) \\
\hline & & 17 & $\begin{array}{l}\text { Expression } \geq 7 \% \text { associated } \\
\text { with shorter DFS }\end{array}$ & Morimoto et al. (2008) \\
\hline & & 52 & $\begin{array}{l}\text { Expression } \geq 22 \% \text { associated } \\
\text { with shorter DFS }\end{array}$ & Duregon et al. $(2014 a, b)$ \\
\hline & & $\begin{array}{l}319+250 \text { (validation } \\
\text { cohort) patients } \\
\text { with R0 resection }\end{array}$ & $\begin{array}{l}\text { Ki67 LI }<10 \%, 10-19 \% \text { and } \\
\geq 20 \% \text { associated with } \\
\text { different classes of DFS } \\
\text { and OS }\end{array}$ & Beuschlein et al. (2015) \\
\hline & & 56 pediatric patients & $\begin{array}{l}\text { Ki67 LI } \geq 15 \% \text { and } M K I 67 \\
\text { overexpression associated } \\
\text { with shorter DFS }\end{array}$ & Pinto et al. (2017) \\
\hline Beta-catenin & $\begin{array}{l}\text { Cell proliferation and } \\
\text { adrenocortical } \\
\text { tumorigenesis }\end{array}$ & 79 & $\begin{array}{l}\text { Nuclear staining associated } \\
\text { with shorter DFS and OS }\end{array}$ & Gaujoux et al. (2011) \\
\hline Cyclin E & Cell proliferation & 49 & $\begin{array}{l}\mathrm{LI} \geq 5 \% \text { associated with } \\
\text { shorter DFS }\end{array}$ & Tissier et al. (2004) \\
\hline ERCC1 & $\begin{array}{l}\text { DNA repair and resistance } \\
\text { to cisplatin }\end{array}$ & 163 & $\begin{array}{l}\text { H-score }>1 \text { associated with } \\
\text { shorter OS in patients who } \\
\text { received platinum } \\
\text { chemotherapy }\end{array}$ & Ronchi et al. (2009) \\
\hline FATE1 & $\begin{array}{l}\text { ER-mitochondria contacts; } \\
\text { resistance to apoptosis } \\
\text { and chemotherapeutic } \\
\text { drugs }\end{array}$ & 141 & $\begin{array}{l}\text { H-score }>1 \text { associated with } \\
\text { shorter OS i }\end{array}$ & $\begin{array}{l}\text { Doghman-Bouguerra } \\
\text { et al. (2016) }\end{array}$ \\
\hline \multirow[t]{2}{*}{ GLUT1 } & \multirow[t]{2}{*}{ Glucose transporter } & 167 & $\begin{array}{l}\text { High expression associated } \\
\text { with shorter OS }\end{array}$ & Fenske et al. (2009) \\
\hline & & 78 & $\begin{array}{l}\text { High expression associated } \\
\text { with shorter DFS and OS }\end{array}$ & Pinheiro et al. (2015) \\
\hline MCT1 & $\begin{array}{l}\text { Monocarboxylate } \\
\text { transporter }\end{array}$ & 78 & $\begin{array}{l}\text { High expression associated } \\
\text { with shorter OS }\end{array}$ & Pinheiro et al. (2015) \\
\hline MCT2 & $\begin{array}{l}\text { Monocarboxylate } \\
\text { transporter }\end{array}$ & 78 & $\begin{array}{l}\text { High expression associated } \\
\text { with increased OS }\end{array}$ & Pinheiro et al. (2015) \\
\hline CAIX & $\begin{array}{l}\text { Carbonic anhydrase ( } \mathrm{pH} \\
\text { regulator) }\end{array}$ & 78 & $\begin{array}{l}\text { High expression associated } \\
\text { with shorter OS }\end{array}$ & Pinheiro et al. (2015) \\
\hline JAG 1 & Notch ligand & $\begin{array}{l}178+77 \text { (validation } \\
\text { cohort) }\end{array}$ & $\begin{array}{l}\text { High expression associated } \\
\text { with longer DFS and OS }\end{array}$ & Ronchi et al. (2015) \\
\hline MMP-2 & $\begin{array}{l}\text { Breakdown of extracellular } \\
\text { matrix }\end{array}$ & 50 & $\begin{array}{l}\text { Expression }>20 \% \text { associated } \\
\text { with shorter DFS and OS }\end{array}$ & Volante et al. (2006) \\
\hline Phospho-histone H3 & Cell proliferation & 52 & $\begin{array}{l}\text { Expression }>9 \% \text { marginally } \\
\text { associated with shorter OS }\end{array}$ & Duregon et al. $(2014 a, b)$ \\
\hline \multirow[t]{2}{*}{ SF-1 } & \multirow[t]{2}{*}{$\begin{array}{l}\text { Steroidogenesis and } \\
\text { adrenocortical cell } \\
\text { proliferation }\end{array}$} & $\begin{array}{l}130+58 \text { (validation } \\
\text { cohort) }\end{array}$ & $\begin{array}{l}\text { High expression associated } \\
\text { with shorter DFS and OS }\end{array}$ & Sbiera et al. (2010) \\
\hline & & 75 & $\begin{array}{l}\text { High expression associated } \\
\text { with shorter OS }\end{array}$ & Duregon et al. (2013a) \\
\hline SGK1 & $\begin{array}{l}\text { Growth factor - regulated } \\
\text { protein kinase }\end{array}$ & 203 & $\begin{array}{l}\text { Low expression associated } \\
\text { with shorter OS }\end{array}$ & Ronchi et al. (2012) \\
\hline \multirow[t]{2}{*}{ VAV2 } & \multirow[t]{2}{*}{$\begin{array}{l}\text { Cytoskeletal remodeling } \\
\text { and tumor cell invasion }\end{array}$} & 105 & $\begin{array}{l}\text { H-score }>1 \text { associated with } \\
\text { shorter DFS and OS }\end{array}$ & Ruggiero et al. (2017) \\
\hline & & 171 & $\begin{array}{l}\text { H-score >1 associated with } \\
\text { shorter DFS and OS; } \\
\text { combined assessment of } \\
\text { VAV2 expression and Ki67 } \\
\text { LI improves prognostic } \\
\text { power }\end{array}$ & Sbiera et al. (2017) \\
\hline
\end{tabular}

DFS, disease-free survival; NA, not available; OS, overall survival. 
that only in rare cases has the features of malignancy (Berthon et al. 2010, Heaton et al. 2012);

- high expression of the G1 cyclin E, which is involved in cell proliferation, is associated with shorter DFS (Tissier et al. 2004);

- high levels of excision repair cross-complementing group 1 (ERCC1) protein, involved in nucleotide excision repair of DNA, correlate with reduced OS selectively in ACC patients who received platinumbased chemotherapy (Ronchi et al. 2009);

- FATE1 is a cancer-testis antigen localized at the interface between the endoplasmic reticulum and mitochondria that modulates calcium-mediated apoptosis in adrenocortical cells. High FATE1 levels are associated with reduced OS (Doghman-Bouguerra et al. 2016);

- high expression of the glucose transporter GLUT1 is associated with reduced OS (Fenske et al. 2009, Pinheiro et al. 2015) and reduced DFS (Pinheiro et al. 2015). In the latter study, high levels of the monocarboxylate transporter (MCT) MCT1, which allows lactate to enter the cell, and the $\mathrm{pH}$ regulator carbonic anhydrase IX (CAIX) were also associated with shorter OS, while a high expression of MCT2, which pumps lactate outside the cell, was associated with increased OS. These results suggest that an increased glycolytic metabolism has a

A
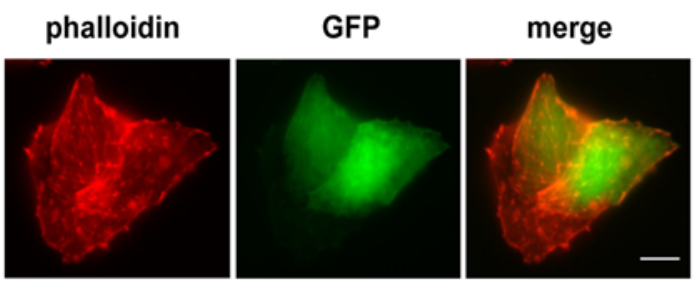

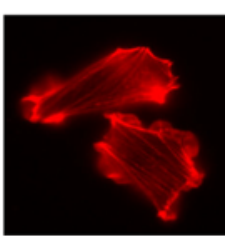

phalloidin

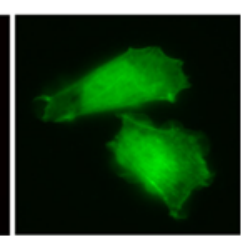

GFP-VAV2

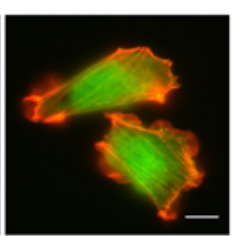

merge role in the determination of an aggressive phenotype in ACC;

- following binding of ligands belonging to either the Jagged or the Delta-like families to Notch transmembrane receptors, the integral membrane $\gamma$-secretase complex cleaves Notch and releases the NICD (cleaved Notch intracellular domain). This translocates to the nucleus to interact with constitutively DNA-bound CSL transcription factors, this way allowing recruitment of the Mastermind-like (MAML) coactivator and stimulating transcription of Notch target genes, such as the HES (hairy enhancer of split) family of transcription factors (Bray 2006). The Notch ligand JAG1 is upregulated in ACC compared to normal adrenal adenomas and ACAs and has an important role in regulating mouse Y1 adrenocortical cell proliferation (Simon et al. 2012). Conversely, high JAG1 expression correlates with longer DFS and OS in ACC (Ronchi et al. 2015);

- matrix metalloproteinase type 2 (MMP-2) contributes to mediate the process of extracellular matrix degradation by cancer cells. Overexpression of this enzyme involved in metastatic invasion is associated with reduced DFS and OS (Volante et al. 2006);

- staining for phospho-histone H3, a marker for mitotic cells, was shown to have a borderline correlation with

B

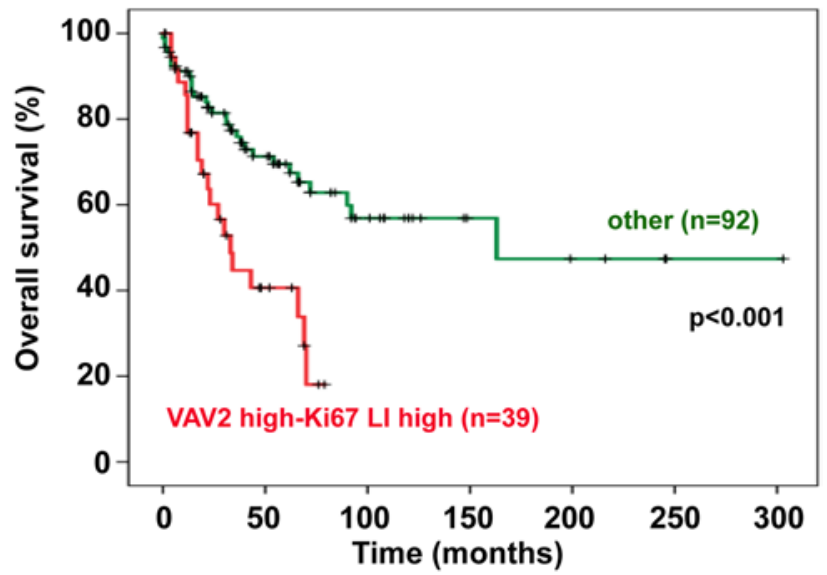

Figure 1

VAV2 overexpression induces cytoskeleton remodeling in H295R cells and is a marker of malignancy in ACC. (A) Cytoskeletal morphology revealed by phalloidin staining (red) in H295R/TR SF-1 cells transfected with vectors encoding either GFP or GFP-VAV2 (green). Scale bars, $5 \mu$ m. Reproduced, with permission, from Ruggiero C, Doghman-Bouguerra M, Sbiera S, Sbiera I, Parsons M, Ragazzon B, Morin A, Robidel R, Favier J \& Bertherat J (2017) Dosage-dependent regulation of VAV2 expression by Steroidogenic actor-1 drives adrenocortical carcinoma cell invasion, Science Signaling, volume 10, eaal2464. Copyright 2017 American Association for the Advancement of Science. (B) OS in ACC patients with both high VAV2 expression ( $H$-score $\geq 2$ ) and high Ki67 LI ( $\geq 20 \%$ ) group (red line) vs all other patients (green line) $P<0.001$, Kaplan-Meier method. Reproduced, with permission, from Sbiera S, Sbiera I, Ruggiero C, Doghman-Bouguerra M, Korpershoek E, de Krijger RR, Haak H, Volante M, Papotti M, Reimondo G, et al. (2017) Assessment of VAV2 expression refines prognostic prediction in adrenocortical carcinoma, Journal of Clinical Endocrinology and Metabolism, volume 102, pages 3491-3498. Copyright 2017 Oxford University Press. 
OS in ACC, which was less significant than mitotic count (Duregon et al. 2014a);

- low expression of serum glucocorticoid kinase 1 (SGK1), an ubiquitous serine/threonine kinase regulated by growth factors, is correlated with shorter OS in ACC (Ronchi et al. 2012);

- Steroidogenic Factor-1 (SF-1) is a transcription factor, belonging to the nuclear receptor superfamily, that has an essential role in the development of adrenal glands and gonads (Lalli 2010). SF-1 expression is a hallmark of ACT and its higher expression levels in ACC are associated with reduced DFS and OS (Sbiera et al. 2010, Duregon et al. 2013b). In ACT cells, SF-1 regulates different sets of target genes according to its dosage (Doghman et al. 2007a, 2013). Some of these dosage-dependent SF-1 target genes have a direct role in decreasing apoptotic death (NOV, FATE1; Doghman et al. 2007b, Doghman-Bouguerra et al. 2016) and increasing invasion of tumor cells (VAV2; Ruggiero et al. 2017). VAV2 is a guanine nucleotide exchange factor regulating cytoskeleton remodelling (Fig. 1A). A recent multicentric study showed that its overexpression is correlated with shorter DFS and OS and that the combined assessment of VAV2 expression and Ki67 LI improves prognostic prediction in ACC (Sbiera et al. 2017) (Fig. 1B). An advantage of VAV2 scoring in prognostic assessment may be its higher intratumoral homogeneity compared to the Ki67 LI.

Molecular markers reveal disease mechanisms and improve patient stratification and prognostication in ACC

Great progress has been made in our understanding of the pathogenesis of ACC and in the improvement of its prognostic assessment, thanks to the molecular analysis of tumors and biological fluids from patients. The majority of the published studies that identified the molecular profiles of ACC has been performed in cohorts including a limited number of patients, mostly because of the rarity of the disease. Nevertheless, molecular assays derived from those studies are in the process of being transferred into routine analysis and it is easy to predict that in the near future, they will become essential in the diagnostic and prognostic workouts of ACC (Armignacco et al. 2017).

The foundation of genomic studies in adult ACC was laid by the analysis of Giordano and collaborators who compared gene expression profiles of 11 ACC, 4 ACA, 1 macronodular hyperplasia and 3 normal adrenal cortices using Affymetrix microarrays (Giordano et al. 2003).
This seminal study identified a cluster of about 90 genes that was differentially expressed in ACC compared to benign tumors, among which a prominent place was occupied by genes related to cell proliferation. In particular, this study confirmed the previously known association of ACC with overexpression of the insulinlike-growth-factor-2 (IGF2). An almost constant finding in ACC is the loss of heterozygosity of the imprinted 11 p15 region with a deletion of the maternal allele and a consequent overexpression of IGF2 (Boulle et al. 1998, Gicquel et al. 2001). The gene expression profiling study by de Fraipont and coworkers confirmed that overexpression of a cluster of genes including IGF2 was a predictor of malignancy in ACC, while high expression of a cluster of genes linked to steroidogenesis was a favorable prognostic indicator (de Fraipont et al. 2005). IGF2 overexpression also characterizes pediatric ACT, but with no association with malignancy (West et al. 2007, Rosati et al. 2008). Further molecular studies showed that gene expression profiles can stratify histologically confirmed adult ACC in 2 subgroups with very different clinical outcomes: one group (C1A), enriched in genes involved in transcription and cell cycle progression, consists of aggressive tumors, while another group (C1B), enriched in genes involved in cell metabolism, intracellular transport, apoptosis and cell differentiation, has mostly an indolent course (de Reyniès et al. 2009, Giordano et al. 2009). In addition, de Reyniès and coworkers showed that the combined expression of the BUB1B and PINK1 transcripts evaluated by RT-qPCR, an indicator derived from transcriptome analysis, is a stage-independent predictor of OS in ACC (de Reyniès et al. 2009). This two-gene molecular predictor has been validated in an independent cohort (Fragoso et al. 2012). Other mRNA markers that have been shown to have prognostic values in ACC are as follows:

- Ribonucleotide reductase large subunit 1 (RRM1) encoding a protein involved in DNA synthesis. High RRM1 expression levels are associated with reduced DFS and OS (Volante et al. 2012);

- Topoisomerase II alpha (TOP2A) is an enzyme responsible for transcription, replication and chromosome condensation and segregation during cell division. High TOP2A expression is correlated with longer time for progression after etoposide doxorubicin - cisplatin - mitotane (EDP-M) treatment (Roca et al. 2017).

MicroRNAs (miRNAs) are a class of evolutionarily conserved, small non-coding RNA molecules which regulate gene expression at the post-transcriptional 
level. They are implicated in virtually every biological process, from development to viral infection, and are also associated with oncogenesis. Several studies have shown a differential expression of a distinct subset of miRNAs in ACC compared with benign ACT (Cherradi 2016, Hassan et al. 2017). Although a certain discrepancy exists about the outcome of different studies, the most consistent modulations of miRNA abundance in ACC compared to benign ACT were reported to be the upregulation of miR483-5p/3p, miR-210 and miR-503 and the downregulation of miR-195, miR-335 and miR-375. In the study by Soon and coworkers, high miR-483-5p and low miR-195 expressions were significantly correlated with shorter DFS (Soon et al. 2009).

RNA studies in clinical specimens are difficult to perform because of the need for frozen, well-preserved tissue for analysis. For this reason, many efforts have been made to identify other more resilient prognostic markers such as DNA markers. Tumor DNA analysis has shown that a cluster of specific genomic alterations has a significant realtionship with OS in ACC (Barreau et al. 2012). Another important prognostic molecular feature in ACC is DNA methylation. Aggressive tumors have a common $\mathrm{CpG}$ island methylator phenotype (CIMP) that can be further divided into two subgroups, each one showing different levels of methylation (CIMP-high and CIMP-low), with CIMP-high tumors having the less favorable prognosis (Rechache et al. 2012, Fonseca et al. 2012, Barreau et al. 2013). An important step toward the introduction of DNA methylation as a clinical prognostic marker is represented by a recent study that showed a robust correlation in ACC patients between DFS/OS and DNA hypermethylation, measured by only 4 probes using a methylation-specific multiplex ligation-dependent probe amplification assay that is amenable to implementation in routine analysis (Jouinot et al. 2017).

Recently, it has been possible to integrate multiple genomic data to obtain deeper insights into the pathogenetic mechanisms of ACC and to show a consistent correlation pattern of molecular aberrations and patient prognosis. A European study including 45 cases and validated in an independent cohort of 77 ACC has been the first to show that tumors in the C1A cluster, which is associated with a worse prognosis, have distinct methylation, mRNA and miRNA expression patterns, more frequent mutations in driver genes and higher global mutation rate than tumors belonging to the $\mathrm{C} 1 \mathrm{~B}$ cluster, characterized by more favorable prognosis (Assié et al. 2014). These findings were confirmed by another study performed on 91 ACCs from worldwide centers
(Zheng et al. 2016). In addition to the Wnt pathway (see above), an integrative genomic analysis of ACC revealed recurrent somatic alterations in TP53, 11p15, cell cycle regulation, telomere maintenance, chromatin remodeling and PKA pathway genes (Assié et al. 2014, Juhlin et al. 2015, Zheng et al. 2016, Armignacco et al. 2017). Interestingly, PKA pathway upregulation due to PRKACA-activating mutations is a hallmark of a subset of cortisol-secreting ACAs (Beuschlein et al. 2014, Cao et al. 2014, Goh et al. 2014, Sato et al. 2014). These findings suggest that at least in some cases, ACC may be derived from ACAs (Ronchi et al. 2013). Furthermore, it is well known that germline mutations in tumor suppressor genes (e.g. TP53, MEN1) may predispose to adrenocortical tumorigenesis (Else 2011).

While all those reports were focused on the analysis of nucleic acids, only a few studies performed proteomic analysis of markers able to discriminate between benign and malignant ACTs. Yang and coworkers identified calreticulin and prohibitin as overexpressed in ACC compared to ACA and showed that calreticulin overexpression was significantly associated with increased tumor stage (Yang et al. 2013). Kjellin and coworkers confirmed that the IGF2 is overexpressed at the protein level in ACC compared to benign ACT as well as aldolase A, an enzyme involved in glycolysis, while several proteins belonging to complex I in the mitochondrial respiration chain are downregulated (Kjellin et al. 2014). These findings further suggest (see the study by Pinheiro et al. mentioned earlier) that a metabolic shift toward aerobic glycolysis (Warburg effect) takes place in malignant ACT. More recently, another study confirmed that ACCs harbor significant changes in their glucose metabolic pathways and in addition identified fascin-1 as overexpressed in ACC compared to normal adrenal (Poli et al. 2015). This protein has an important role in cytoskeletal organization and is associated with malignancy in a variety of cancers (Hashimoto et al. 2011). Fascin-1 is an attractive new therapeutic target since specific small molecule inhibitors have been developed and shown to impair metastatic dissemination in preclinical cancer models (Chen et al. 2010, Huang et al. 2015).

\section{Markers of malignancy are different in} pediatric ACT compared to adult

Pediatric ACTs differ from adult tumors under several aspects related to their pathogenesis, clinical presentation, molecular signatures and prognosis (Lalli \& Figueiredo 2015). In addition, histopatological (Weiss score) and molecular (IGF2 overexpression, BUB1B/PINK1 expression) 
parameters linked to malignancy in adult tumors do not have the same predictive value in pediatric ACT (Wieneke et al. 2003, Rosati et al. 2008, Dehner \& Hill 2009, Papotti et al. 2011, Fragoso et al. 2012, Lalli \& Figueiredo 2015). In the comprehensive study from the International Pediatric Adrenocortical Tumor Registry based on the analysis of 254 patients, the major parameters influencing the risk of recurrence were age, stage at diagnosis and tumor weight (Michalkiewicz et al. 2004). After analysis of a series of 83 patients, Wieneke and coworkers proposed a set of 9 macroscopic and microscopic criteria for the diagnosis of malignancy in pediatric ACT (Wieneke et al. 2003), further validated in other series (Magro et al. 2012, Das et al. 2016). Transcriptome analysis of pediatric ACT revealed that HLA class II gene expression was downregulated in tumors classified histologically as carcinomas (West et al. 2007). A subsequent immunohistochemical study validated those data showing that MHC class II expression was significantly higher in benign compared to malignant ACT and was associated with longer DFS. Among HLA class II antigens, HLA-DPA1 expression was most significantly associated with DFS after adjustment for tumor weight and stage (Pinto et al. 2016). Integrative analysis of genomic alterations of pediatric ACT identified a highrisk group characterized by concomitant TP53 and ATRX mutations, massive structural variations and frequent background mutations and higher expression of genes associated with chromosome instability and cell cycle (Pinto et al. 2015). A recent study in pediatric ACT showed that an elevated KI67 LI and MKI67 overexpression are associated with reduced DFS. Interestingly, a correlation was reported between MKI67 overexpression and low HLA-DPA1 expression (Pinto et al. 2017).

\section{The 'liquid biopsy' and circulating markers of malignancy}

As in other solid tumor types, it would be extremely important for the clinician to count on minimally invasive markers of malignancy in patients with ACC to improve their stratification for prognostic and therapeutic purposes. In particular, markers that can be obtained by sampling from minimally invasive and easily accessible biological fluids, such as blood, urine and saliva, would be pivotal not only for diagnostic and prognostic purposes but also for continuous monitoring of patients during follow-up. The liquid biopsy is referred to a simple blood draw that can provide material released from the tumor into the bloodstream, such as circulating tumor cells (CTCs), miRNAs, exosomes and cell-free DNA of tumor

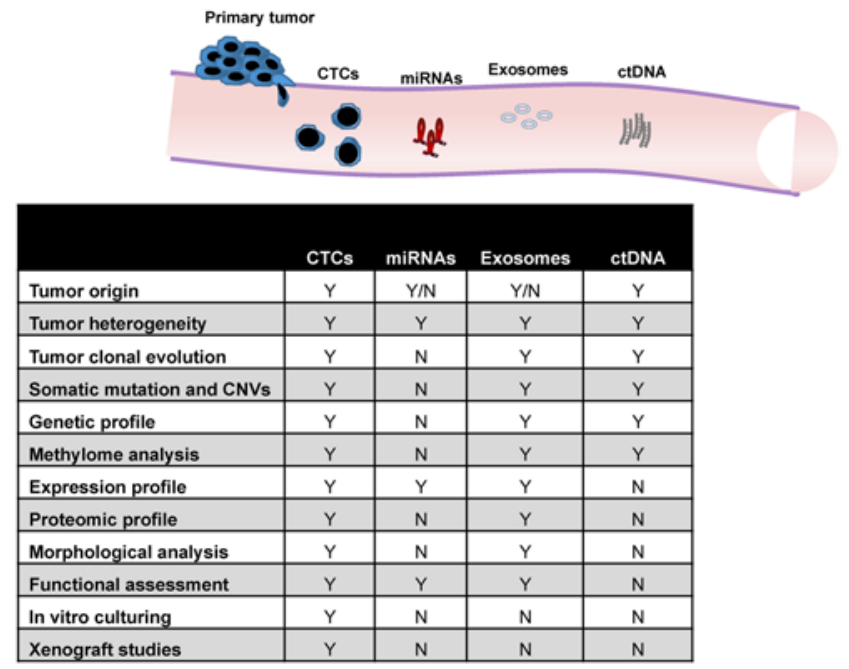

Figure 2

The liquid biopsy consists of a blood draw containing CTCs, miRNAs, exosomes and ctDNAs deriving from the tumor mass. Head-to-head comparison between the applications of the different entities that can be isolated from the liquid biopsy is shown in the table. Y, yes; N, no.

origin (ctDNA) (Fig. 2). This is a novel and minimally invasive technique developed for solid tumors and recently also applied to ACC (Chabre et al. 2013, Szabó et al. 2014, Creemers et al. 2017, Batth et al. 2017, Bardelli \& Pantel 2017) to identify potential markers to assess malignancy in ACC, even if the predictive power needs to be confirmed on larger cohorts of patients. In addition to its diagnostic/ prognostic value, the liquid biopsy represents a unique tool that can provide informative material to be analyzed and compared to the primary lesion for longitudinal surveillance of clonal evolution and progression of the tumor, also in response to anticancer treatments. All this information is pivotal for the development of personalized medicine approaches (Siravegna et al. 2017). In particular, both clonal analysis and tumor monitoring during follow-up cannot be effectively achieved using the currently available tumor tissue specimens.

\section{CTCs: metastatic cells caught in the act?}

The presence of CTCs of adrenal origin has recently been characterized in patients affected by ACC compared to benign adenomas (Pinzani et al. 2013). These cells are characterized by specific morphological traits, such as nucleocytoplasmic ratio $\geq 50 \%$, irregular nuclear shape, hyperchromatic nucleus, basophilic cytoplasm and cell size $\geq 16 \mu \mathrm{m}$ (Pinzani et al. 2013). In particular, the last trait enables their trapping through blood filtration on specific size-selective filter devices (ScreenCell). 
This technique is particularly useful in ACC (Fig. 3A and B), since CTC sorting on the basis of epithelial cell adhesion molecule (EpCAM) surface exposure is tricky and might lead to underestimation in this cancer, which has been demonstrated to be negative for EpCAM (Went et al. 2004). Conversely, the enrichment by size associated with the positivity for the adrenal-specific marker SF-1 (Fig. 3C) resulted in finding of a significant correlation between the number of CTCs/mL and the tumor diameter or the tumor stage (Pinzani et al. 2013), suggesting that CTCs may be a useful marker in aggressive/metastatic ACC. CTCs may be isolated or arranged in groups of 3-20 cells (circulating tumor microemboli, CTMs) which are detached together from the primary lesion. CTMs seem to be more prone to metastatize than single CTC and their presence/number is a poor prognostic factor in solid tumors (Hou et al. 2012, Chang et al. 2016).

Meta-analyses of studies identifying CTCs in breast cancer (Zhang et al. 2012), colorectal cancer (Rahbari et al. 2010) and melanoma (Mocellin et al. 2006) revealed a robust prognostic value of CTCs in those tumors. Interestingly, CTCs, despite decreased in number, can be detactable in the blood long time after tumor removal, indicating that a reservoir could be present in the bone marrow, as suggested for breast cancer (Wiedswang et al. 2006). Thanks to the recent progress made in the genetic analysis of single cells, the genomic profile of even the few CTCs recovered from the bloodstream could be obtained and compared with that of the primary lesion and of the eventual metastasis in order to gain insight into the heterogeneity of ACC. This heterogeneity is the basis for the selection of those specific clones able to enter the bloodstream, and among those CTCs, heterogeneity further drives the ones with potential of metastasizing (Salvianti \& Pinzani 2017, Siravegna et al. 2017). Moving forward from the initial preliminary studies, several ongoing clinical trials assessing CTCs in different tumors have been designed to validate in large patient cohorts the use of CTCs for diagnostic/prognostic disease-monitoring purposes (see Wang et al. (2017) for a review). In rare cancers such as ACC, an effort to set up multicenter studies is urgently needed in order to assess a CTC prognostic value in metastatic tumors.

\section{Circulating miRNAs}

It is now well known that miRNAs produced by cancer cells are passively and/or actively shedded into the circulation and that their serum/plasma levels may be correlated with malignancy in different tumor types, including ACC (Cherradi 2016, Hassan et al. 2017).

Among the different circulating miRNA profiles characterized in ACC (Szabó et al. 2014), miR-483-5p is the recurrent one in almost all the studies and the most suggestive one as it maps in the second intron of the IGF2 gene, whose hyperexpression is a recurrent tract of aggressive ACC (Giordano et al. 2009). Indeed, miR483-5p has been demonstrated to be overexpressed both in the primary tumor (Soon et al. 2009, Patterson et al. 2011, Duregon et al. 2014b) and the bloodstream (Chabre et al. 2013, Patel et al. 2013, Szabó et al. 2014). Chabre and coworkers showed that high circulating serum levels of miR-483-5p and low circulating levels of miR-195 in 21 ACCs stratified into non-aggressive and aggressive cancers
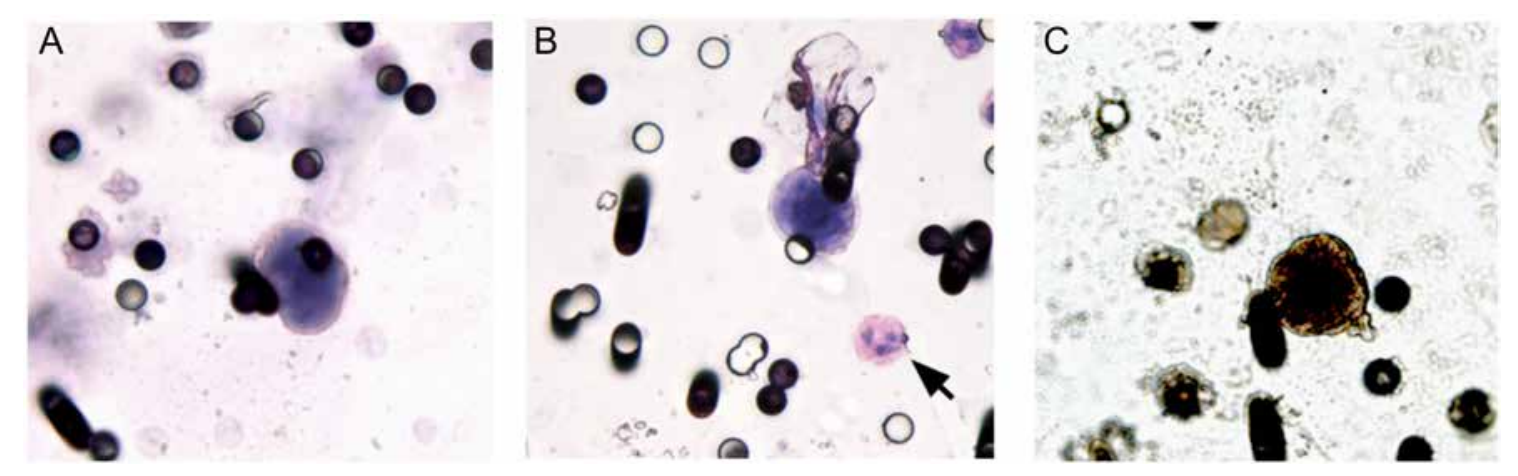

Figure 3

Microscopic evaluation of CTCs enriched by size of specific filter devices. (A and B) Hematoxylin/eosin staining identifies CTCs as large cells with a high nucleus/cytosol ratio; the arrow indicates a polymorphonuclear leukocyte for comparison; micropores of the ScreenCellTM filter devices (black holes) have a diameter of $8 \mu \mathrm{m}$. (C) Immunohistochemistry on CTC shows positivity for nuclear SF-1, indicating adrenal origin. Reproduced, with permission, from Pinzani P, Scatena C, Salvianti F, Corsini E, Canu L, Poli G, Paglierani M, Piccini V, Pazzagli M, Nesi G, et al. (2013) Detection of circulating tumor cells in patients with adrenocortical carcinoma: a monocentric preliminary study, Journal of Clinical Endocrinology and Metabolism, volume 98 , pages 3731-3738. Copyright 2013 Oxford University Press. 
were associated with both shorter DFS and OS (Chabre et al. 2013). Salvianti and coworkers went further, as they developed an absolute method to measure plasma miR-483-5p levels that could be easily transferred to the routine analysis (Salvianti et al. 2017). A cut-off value of $221 \mathrm{ng} / \mathrm{mL}$ equivalent is able to significantly discriminate between aggressive (stages 3 and 4) and non-aggressive (stages 1 and 2) ACCs in a cohort of 27 ACCs, predicting DFS and OS in a Kaplan-Meier analysis (Salvianti et al. 2017). Notably, miR-483-5p levels significantly correlate with CTC number in the same blood sample, suggesting a direct release of these cells from the tumor (Salvianti et al. 2017). Importantly, standardization of pre-analytical procedures and absolute/relative analysis are mandatory to use information derived from circulating miRNA for ACC prognostication.

\section{Exosomes and tumor microenvironment in ACC progression}

Exosomes are $40-100 \mathrm{~nm}$ diameter particles actively released in extracellular space and body fluids by exocytosis from almost all cell types, including tumor cells. As they contain proteins, lipids, DNA, mRNA and miRNAs, they have been suggested to play a pivotal role in exchanging information between cells, in particular between tumor cells and their microenvironment. Indeed, the tumor cells 'educate' the surrounding stromal cells in the microenvironment (fibroblasts, endothelial cells, preadipocytes) to modify their functions and metabolism in order to support tumor progression (Cirri \& Chiarugi 2012, Chiarugi \& Cirri 2016). On the other hand, the surrounding stroma responds and interacts with the tumor cells exchanging pivotal factors through these exosomal cargoes. In particular, exosomes have been demonstrated to support the metastatic process both locally and at distance by affecting the potential metastatic organs. Exosomes released by tumor cells and environmental stroma appear critical for supporting processes involved in metastasis, such as angiogenesis, tumor invasion, extracellular matrix digestion, cell motility and immunomodulatory escape activity of the tumor (Milane et al. 2015, Suchorska \& Lach 2016). Exosomes are recruited at the plasma membrane of tumor cell invadopodia, the tumor cell structures which release metalloproteinases for extracellular matrix degradation (Hoshino et al. 2013, Mu et al. 2013). Transfer of exosomes extracted from tumor provided with invadopodia induces invadopodia formation in non-invading cells (Hoshino et al. 2013). Moreover, the ability of the cancer-released exosomes to influence the stromal 'premetastatic' niche in the potential target metastatic organs has recently been hypothesized. Through organ-specific delivery of these so-called metastasomes, cancer cells from the primary tumor or CTCs would prepare the soil in the target organs for the metastatic colonization (Ghasemi et al. 2013).

Notably, Wnt5A signaling has been shown to induce active metastasis-driving exosome formation in melanoma (Ekström et al. 2014). This mechanism could also be relevant in ACC, where Wnt signaling activating mutations have been described to be the most frequent tumor mutations (Assié et al. 2014, Zheng et al. 2016).

Extracellular vesicle-associated miR-483-5p isolated from plasma samples of a cohort of 18 ACCs and 16 ACAs has been recently reported to have a high significant diagnostic power (Perge et al. 2017), further indicating the relevance of miR-483-5p in ACC; however, further studies are required to assess exosome miR-483-5p importance in metastatic ACC.

\section{Circulating cell-free DNA (cfDNA) and cell-free tumor DNA (ctDNA)}

Finally, the liquid biopsy can also provide circulating cfDNA, derived from non-tumoral and tumoral cells (ctDNA). The exact mechanism by which the tumor releases DNA into the bloodstream is still obscure, although necrosis and apoptosis, often occurring in the tumoral mass, might be involved. The circulating levels of ctDNA largely depend on the tumor type, diameter, disease stage and therapeutic response (Bettegowda et al. 2014). Being essentially a waste product, the quality of this DNA is very poor and together with its extremely low levels makes the analysis of genomic profile and methylation state quite difficult (Perdigones \& Murtaza 2017). For this reason, the development of highly sensitive and highthroughput technologies, such as digital PCR and Next Generation Sequencing, only recently enabled to obtain ctDNA profiling and compare it with the profile of the primary lesion to gain insight into the heterogeneity and clonal evolution of the tumor (Ignatiadis et al. 2015, Perdigones \& Murtaza 2017, Salvianti \& Pinzani 2017, Siravegna et al. 2017). For ACC, the knowledge of single mutations in driver genes and copy number variations (CNVs) identified in the primary lesion will be pivotal to guide the analysis of ctDNA in ACC patients. Creemers and coworkers were the first to report the presence of circulating ctDNA in plasma of a metastastic ACC patient following mutation identification in the primary tumor (Creemers et al. 2017). However, the same authors were 
not able to detect in ctDNA the same mutations already characterized in the primary tumor, suggesting that mutation detection in ctDNA using the current approach may be variable between ACC patients.

Taking together these findings, among the variety of tumor material that can be isolated by a non-invasive liquid biopsy, only CTCs and ctDNA can be univocally linked to the primary lesion. In fact, for CTCs, organspecific markers or the presence of mutation/CNVs also detected in the primary lesion can demonstrate the origin of these circulating cells (Fig. 3). Conversely, for exosomes, it depends on their content, while for miRNAs, their production by cells different from the tumor cannot be ruled out. CTCs also enable us to study not only the genetic and methylomic profiles of the tumor cells entering the circulation, but also gene and protein expressions, thus providing useful information to understand the metastatic process and the tumor cell factors involved (Fig. 2). Moreover, although very few attempts have been made so far, CTCs could be cultured in vitro (Yu et al. 2014, Cayrefourcq et al. 2015) and used to derive patient-personalized xenograft models (Baccelli et al. 2013, Khoo et al. 2016) (Fig. 2) which can allow to screen novel, more efficient drugs selective for metastatic tumors rather than the primary lesion.

\section{Animal models of metastatic ACT}

Up to a very recent time, mouse models of metastatic ACT have been lacking. At best, only sporadic local dissemination and virtually no distant metastases were observed in the available mouse models (Basham et al. 2016, Leccia et al. 2016). However, the situation changed in 2017: a breakthrough has been made by the publication of the first mouse model developing differentiated ACC able to produce metastases with high frequency (BatisseLignier et al. 2017). In those mice, the SV 40 large T antigen, which sequesters and inactivates p53 and $\mathrm{Rb}$, is produced in the adrenal cortex under the control of the $0.5-\mathrm{kb}$ $A k r 1 b 7$ promoter/intron regulatory sequences, whose expression is restricted to the adrenal zona fasciculata (AdTag mice). This transgenic strategy targets two critical tumor suppressors frequently mutated in human ACC (Assié et al. 2014, Zheng et al. 2016). AdTag mice present adrenal nodular lesions that develop morphological and histopathological characteristics of malignancy worsening with age and are associated with primary hypercorticism. Importantly, at 8 months of age, metastases are found at high frequency in the lungs, liver and other tissues. Therefore, AdTag mice represent a unique and invaluable tool to study the molecular mechanisms involved in ACC pathogenesis in an immunocompetent host and to test new pharmacological treatments for disseminated ACC. Interestingly, Batisse-Lignier and coworkers also showed that long-term mice treatment with rapamycin (an inhibitor of mTOR signaling) significantly reduced tumor size and hormonal production. These data are consistent with previous studies showing the efficacy of mTOR and dual PI3K/mTOR inhibitors to impair H295R cell proliferation both in vitro and grown as xenografts in nude mice (Doghman et al. 2010, Doghman \& Lalli 2012, Poli et al. 2016).

Xenografts in immunodeficient mice are the only available method to study the ability of human ACC cells (both cell lines and patient-derived primary cells) to form tumors and their drug sensitivity in preclinical studies (Luconi \& Mannelli 2012, Hantel \& Beuschlein 2015). The most widely used cell line for xenograft experiments is H295R (Logié et al. 2000), even if the recently described SJ-ACC3 (only growing as xenografts; Pinto et al. 2013) and MUC-1 (xenografts and cell line; Hantel et al. 2016) hold promise to enlarge the representation of the spectrum of heterogeneity present in human tumors. We need to underline here that the SW-13 cell line that has been used in several studies, derived from a metastasis of a small cell carcinoma in the adrenal cortex, does NOT express markers of adrenocortical differentiation and as such is not a valid model for human ACC. Important progress has recently been made in the domain of xenograft models for ACC with the report of a method to induce metastatic dissemination of H295R cells. Since subcutaneous H295R xenografts in nude mice show no tendency to metastasize, Morin and coworkers tested several alternative methods to obtain liver metastases. The most efficient method resulted from tumor cell injection in the spleen followed by splenectomy to avoid local cell growth and to allow enough time for cells to form metastases detectable by bioluminescence (Morin et al. 2017). Bypassing the stages of local invasion and intravasation of tumor cells, this method has limitations. Nevertheless, it genuinely represents the later stages of the metastatization process (see 'An introduction to the metastatic process' section above), which are often ratelimiting (Luzzi et al. 1998). For these reasons, this model appears valuable for studies concerning the human disease and to test new therapies for metastatic ACC.

\section{Perspectives}

Current therapies are only marginally efficient against metastatic ACC. The cornerstone for the treatment of 
metastatic disease is mitotane (o, $\left.\mathrm{p}^{\prime}-\mathrm{DDD}\right)$, a drug provided with both antihormonal and antitumoral activities (Terzolo et al. 2007, Else et al. 2014, Creemers et al. 2016). This compound is commonly associated with EDP polychemotherapy in patients with rapidly progressive disease, but this regimen does not substantially improve OS of patients (Fassnacht et al. 2012). Alternative therapies to treat metastatic ACC are therefore urgently needed. Initial hopes in IGF-1R antagonists, spurred by data indicating the importance of IGF2-IGF-1R signaling in controlling ACC cell proliferation, were dashed by the results of a study which on the whole showed no improvement in either DFS or OS in patients with locally advanced or metastatic ACC treated with the oral IGF-1R inhibitor linsitinib (OSI-906) (Fassnacht et al. 2015). However, a partial response was observed in a small group of patients treated with the drug. These findings further highlight the molecular heterogeneity that characterizes ACC and affects the results obtained by a single therapy approach. In addition, they suggest that a comprehensive molecular characterization of the tumor might identify those cases that could be predicted to be responsive to IGF-1R inhibitors or other targeted therapies. But what about nonresponders? Future therapies for metastatic ACC should probably be oriented to target already-disseminated tumor cells and impair their growth into clinically relevant macroscopic metastases, since this is the limiting step in the metastatization process for most carcinomas (Valastyan \& Weinberg 2011). To this purpose, it will be essential to obtain an extensive molecular and genomic characterization of metastases as compared to their primary tumors in order to identify potential genetic and epigenetic drivers of the metastatic process. According to the findings so far presented, the prognostic classification of ACC based on integrated histopathological and genomic parameters of primary tumors seems to suggest that ACCs ab initio possess features able to influence their spreading and metastasizing ability. However, at this stage of knowledge, acquisition of further alterations in the context of a milieu predisposing the tumor cells toward a metastatic fate cannot be ruled out. Another important aspect to be considered is the intratumor heterogeneity. It is presently unknown to which extent heterogeneity exists within an individual ACC, which may reflect tumor evolution and give rise to subclonal populations with different functional properties, influencing resistance to therapy and metastasizing ability. Heterogeneity occurring in ACC is strongly supported by the observation that Ki67 labeling may vary widely from one area of the tumor to another (Duregon et al. 2015). This is likely determined by intratumoral differences in genetic and/or epigenetic profiles. Accordingly, histopathologic analysis of ACC often reveals areas with distinct cellular features, including nuclear pleomorphism, cytoplasmic aspect and tumor architecture. Altogether, these data suggest that tumor heterogeneity plays an important role in ACC biology, with a potential direct impact on its metastatic ability and response to treatment. Immunotherapy will probably also have an important role to boost the immune system to hold a grip on tumor cells disseminated in peripheral organs. Another relevant therapeutic avenue to be explored will be the modulation of the microenvironment in the primary organ (from which subclones with metastatic properties may evolve) as well as the microenvironment in metastasis-prone organs, with the purpose to make them more hostile to thriving of tumor cells. Finally, after elucidating the nature of RNA and DNA alterations involved in ACC pathogenesis, research now needs to move on the analysis of the aberrations in the ACC proteome and metabolome, which may reveal important new therapeutic targets. The new animal models today available for studying metastatic ACC will undoubtedly provide essential tools both to understand the molecular mechanisms underlying metastatic dissemination and growth and to test novel targeted therapies in the era of precision medicine.

\section{Declaration of interest}

The author declare that there is no conflict of interest that could be perceived as prejudicing the impartiality of this review.

\section{Funding}

This work was supported by Associazione Italiana Ricerca sul Cancro AIRC (prot. IG2015-17691 to M L). E L was the recipient of a Visiting Professor grant from the University of Florence. The authors are members of the ENS@T (European Network for the Study of Adrenal Tumors).

\section{References}

Armignacco R, Cantini G, Canu L, Poli G, Ercolino T, Mannelli M \& Luconi M 2017 Adrenocortical carcinoma: the dawn of a new era of genomic and molecular biology analysis. Journal of Endocrinological Investigation [epub]. (https://doi.org/10.1007/s40618-017-0775-y)

Assié G, Letouzé E, Fassnacht M, Jouinot A, Luscap W, Barreau O, Omeiri H, Rodriguez S, Perlemoine K, René-Corail F, et al. 2014 Integrated genomic characterization of adrenocortical carcinoma. Nature Genetics 46 607-612. (https://doi.org/10.1038/ng.2953)

Aubert S, Wacrenier A, Leroy X, Devos P, Carnaille B, Proye C, Wemeau JL, Lecomte-Houcke M \& Leteurtre E 2002 Weiss system revisited: a clinicopathologic and immunohistochemical study of 49 adrenocortical tumors. American Journal of Surgical Pathology 26 1612-1619. (https://doi.org/10.1097/00000478-200212000-00009) 
Baccelli I, Schneeweiss A, Riethdorf S, Stenzinger A, Schillert A, Vogel V, Klein C, Saini M, Bäuerle T, Wallwiener M, et al. 2013 Identification of a population of blood circulating tumor cells from breast cancer patients that initiates metastasis in a xenograft assay. Nature Biotechnology 31 539-644. (https://doi.org/10.1038/nbt.2576)

Bardelli A \& Pantel K 2017 Liquid biopsies, what we do not know (yet). Cancer Cell 31 172-179. (https://doi.org/10.1016/j.ccell.2017.01.002)

Barreau O, de Reynies A, Wilmot-Roussel H, Guillaud-Bataille M, Auzan C, René-Corail F, Tissier F, Dousset B, Bertagna X, Bertherat J, et al. 2012 Clinical and pathophysiological implications of chromosomal alterations in adrenocortical tumors: an integrated genomic approach. Journal of Clinical Endocrinology and Metabolism 97 E301-E311. (https://doi.org/10.1210/jc.2011-1588)

Barreau O, Assié G, Wilmot-Roussel H, Ragazzon B, Baudry C, Perlemoine K, René-Corail F, Bertagna X, Dousset B, Hamzaoui N, et al. 2013 Identification of a CpG island methylator phenotype in adrenocortical carcinomas. Journal of Clinical Endocrinology and Metabolism 98 E174-E184. (https://doi.org/10.1210/jc.2012-2993)

Basham KJ, Hung HA, Lerario AM \& Hammer GD 2016 Mouse models of adrenocortical tumors. Molecular and Cellular Endocrinology 21 82-97. (https://doi.org/10.1016/j.mce.2015.11.031)

Batisse-Lignier M, Sahut-Barnola I, Tissier F, Dumontet T, Mathieu M, Drelon C, Pointud JC, Damon-Soubeyrand C, Marceau G, Kemeny JL, et al. 2017 P53/Rb inhibition induces metastatic adrenocortical carcinomas in a preclinical transgenic model. Oncogene 36 4445-4456. (https://doi.org/10.1038/onc.2017.54)

Batth IS, Mitra A, Manier S, Ghobrial IM, Menter D, Kopetz S \& Li S 2017 Circulating tumor markers: harmonizing the yin and yang of CTCs and ctDNA for precision medicine. Annals of Oncology $\mathbf{2 8}$ 468-477. (https://doi.org/10.1093/annonc/mdw619)

Berthon A, Sahut-Barnola I, Lambert-Langlais S, de Joussineau C, Damon-Soubeyrand C, Louiset E, Taketo MM, Tissier F, Bertherat J, Lefrançois-Martinez AM, et al. 2010 Constitutive beta-catenin activation induces adrenal hyperplasia and promotes adrenal cancer development. Human Molecular Genetics 9 1561-1576. (https://doi. org/10.1093/hmg/ddq029)

Bettegowda C, Sausen M, Leary RJ, Kinde I, Wang Y, Agrawal N, Bartlett BR, Wang H, Luber B, Alani RM, et al. 2014 Detection of circulating tumor DNA in early- and late-stage human malignancies. Science Translational Medicine 6 224ra24. (https://doi.org/10.1126/ scitranslmed.3007094)

Beuschlein F, Fassnacht M, Assié G, Calebiro D, Stratakis CA, Osswald A Ronchi CL, Wieland T, Sbiera S, Faucz FR, et al. 2014 Constitutive activation of PKA catalytic subunit in adrenal Cushing's syndrome. New England Journal of Medicine 370 1019-1028. (https://doi. org/10.1056/NEJMoa1310359)

Beuschlein F, Weigel J, Saeger W, Kroiss M, Wild V, Daffara F, Libé R, Ardito A, Al Ghuzlan A, Quinkler M, et al. 2015 Major prognostic role of Ki67 in localized adrenocortical carcinoma after complete resection. Journal of Clinical Endocrinology and Metabolism 100 841-849. (https://doi.org/10.1210/jc.2014-3182)

Boulle N, Logié A, Gicquel C, Perin L \& Le Bouc Y 1998 Increased levels of insulin-like growth factor II (IGF-II) and IGF-binding protein-2 are associated with malignancy in sporadic adrenocortical tumors. Journal of Clinical Endocrinology and Metabolism 83 1713-1720. (https://doi.org/10.1210/jcem.83.5.4816)

Bray SJ 2006 Notch signalling: a simple pathway becomes complex. Nature Reviews Molecular and Cell Biology 7 678-689. (https://doi. org/10.1038/nrm2009)

Cao Y, He M, Gao Z, Peng Y, Li Y, Li L, Zhou W, Li X, Zhong X, Lei Y, et al. 2014 Activating hotspot L205R mutation in PRKACA and adrenal Cushing's syndrome. Science 344 913-917. (https://doi.org/10.1126/ science.1249480)

Cayrefourcq L, Mazard T, Joosse S, Solassol J, Ramos J, Assenat E, Schumacher U, Costes V, Maudelonde T, Pantel K, et al. 2015 Establishment and characterization of a cell line from human circulating colon cancer cells. Cancer Research 75 892-901. (https:// doi.org/10.1158/0008-5472.CAN-14-2613)

Chabre O, Libé R, Assie G, Barreau O, Bertherat J, Bertagna X, Feige JJ \& Cherradi N 2013 Serum miR-483-5p and miR-195 are predictive of recurrence risk in adrenocortical cancer patients. Endocrine-Related Cancer 20 579-594. (https://doi.org/10.1530/ERC-13-0051)

Chang MC, Chang YT, Chen JY, Jeng YM, Yang CY, Tien YW, Yang SH, Chen HL, Liang TY, Wang CF, et al. 2016 Clinical significance of circulating tumor microemboli as a prognostic marker in patients with pancreatic ductal adenocarcinoma. Clinical Chemistry 62 505-513. (https://doi.org/10.1373/clinchem.2015.248260)

Chen L, Yang S, Jakoncic J, Zhang JJ \& Huang XY 2010 Migrastatin analogues target fascin to block tumour metastasis. Nature 464 1062-1066. (https://doi.org/10.1038/nature08978)

Cherradi N 2016 microRNAs as potential biomarkers in adrenocortical cancer: progress and challenges. Frontiers in Endocrinology 6195. (https://doi.org/10.3389/fendo.2015.00195)

Chiarugi P \& Cirri P 2016 Metabolic exchanges within tumor microenvironment. Cancer Letters 380 272-280. (https://doi. org/10.1016/j.canlet.2015.10.027)

Cirri P \& Chiarugi P 2012 Cancer-associated-fibroblasts and tumour cells: a diabolic liaison driving cancer progression. Cancer and Metastasis Reviews 31 195-208. (https://doi.org/10.1007/s10555-0119340-x)

Clark AG \& Vignjevic DM 2015 Modes of cancer cell invasion and the role of the microenvironment. Current Opinion in Cell Biology 36 13-22. (https://doi.org/10.1016/j.ceb.2015.06.004)

Creemers SG, Hofland LJ, Korpershoek E, Franssen GJH, van Kemenade FJ, Herder WW \& Feelders RA 2016 Future directions in the diagnosis and medical treatment of adrenocortical carcinoma. Endocrine-Related Cancer 23 R43-R69. (https://doi.org/10.1530/ERC15-0452)

Creemers SG, Korpershoek E, Atmodimedjo PN, Dinjens WNM, van Koetsveld PM, Feelders RA \& Hofland LJ 2017 Identification of mutations in cell-free circulating tumor DNA in adrenocortical carcinoma: a case series. Journal of Clinical Endocrinology and Metabolism 102 3611-3615. (https://doi.org/10.1210/jc.2017-00174)

Cuylen S, Blaukopf C, Politi AZ, Müller-Reichert T, Neumann B, Poser I, Ellenberg J, Hyman AA \& Gerlich DW 2016 Ki-67 acts as a biological surfactant to disperse mitotic chromosomes. Nature 535 308-312. (https://doi.org/10.1038/nature18610)

Das S, Sengupta M, Islam N, Roy P, Datta C, Mishra PK, Banerjee S, Chaudhuri MK \& Chatterjee U 2016 Weineke criteria, Ki-67 index and p53 status to study pediatric adrenocortical tumors: is there a correlation? Journal of Pediatric Surgery 51 1795-1800 (https://doi. org/10.1016/j.jpedsurg.2016.07.014)

de Fraipont F, El Atifi M, Cherradi N, Le Moigne G, Defaye G, Houlgatte R, Bertherat J, Bertagna X, Plouin PF, Baudin E, et al. 2005 Gene expression profiling of human adrenocortical tumors using complementary deoxyribonucleic acid microarrays identifies several candidate genes as markers of malignancy. Journal of Clinical Endocrinology and Metabolism 90 1819-1829. (https://doi. org/10.1210/jc.2004-1075)

Dehner LP \& Hill DA 2009 Adrenal cortical neoplasms in children: why so many carcinomas and yet so many survivors? Pediatric and Developmental Pathology 12 284-291. (https://doi.org/10.2350/08-060489.1)

de Reyniès A, Assié G, Rickman DS, Tissier F, Groussin L, René-Corail F, Dousset B, Bertagna X, Clauser E \& Bertherat J 2009 Gene expression profiling reveals a new classification of adrenocortical tumors and identifies molecular predictors of malignancy and survival. Journal of Clinical Oncology 27 1108-1115. (https://doi.org/10.1200/ JCO.2008.18.5678)

Doghman M, Karpova T, Rodrigues GA, Arhatte M, De Moura J, Cavalli LR, Virolle V, Barbry P, Zambetti GP, Figueiredo BC, et al. $2007 a$ Increased Steroidogenic Factor-1 dosage triggers adrenocortical 
cell proliferation and cancer. Molecular Endocrinology 21 2968-2987. (https://doi.org/10.1210/me.2007-0120)

Doghman M, Arhatte M, Thibout H, Rodrigues G, De Moura J, Grosso S, West AN, Laurent M, Mas JC, Bongain A, et al. 2007b

Nephroblastoma overexpressed/cysteine-rich protein 61/connective tissue growth factor/nephroblastoma overexpressed gene-3 (NOV/ CCN3), a selective adrenocortical cell proapoptotic factor, is downregulated in childhood adrenocortical tumors. Journal of Clinical Endocrinology and Metabolism 92 3253-3260. (https://doi. org/10.1210/jc.2007-0342)

Doghman M, Cazareth J \& Lalli E 2009 The T cell factor/beta-catenin antagonist PKF115-584 inhibits proliferation of adrenocortical carcinoma cells. Journal of Clinical Endocrinology and Metabolism 93 3222-3225. (https://doi.org/10.1210/jc.2008-0247)

Doghman M, El Wakil A, Cardinaud B, Thomas E, Wang J, Zhao W, Peralta Delalle MHC, Figueiredo BC, Zambetti GP \& Lalli E 2010 Regulation of insulin-like growth factor - mammalian target of rapamycin signalling by microRNA in childhood adrenocortical tumors. Cancer Research 70 4666-4675. (https://doi. org/10.1158/0008-5472.CAN-09-3970)

Doghman M \& Lalli E 2012 Efficacy of the novel dual PI3-kinase/mTOR inhibitor NVPBEZ235 in a preclinical model of adrenocortical carcinoma. Molecular and Cellular Endocrinology 364 101-104. (https://doi.org/10.1016/j.mce.2012.08.014)

Doghman M, Figueiredo BC, Volante M, Papotti M \& Lalli E 2013 Integrative analysis of SF-1 transcription factor dosage impact on genome-wide binding and gene expression regulation. Nucleic Acids Research 41 8896-8907. (https://doi.org/10.1093/nar/gkt658)

Doghman-Bouguerra M, Granatiero V, Sbiera S, Sbiera I, Lacas-Gervais S, Brau F, Fassnacht M, Rizzuto R \& Lalli E 2016 FATE1 antagonizes calcium- and drug-induced apoptosis by uncoupling ER and mitochondria. EMBO Reports 17 1264-1280. (https://doi. org/10.15252/embr.201541504)

Duregon E, Fassina A, Volante M, Nesi G, Santi R, Gatti G, Cappellesso R, Dalino Ciaramella P, Ventura L, Gambacorta M, et al. $2013 a$ The reticulin algorithm for adrenocortical tumor diagnosis: a multicentric validation study on 245 unpublished cases. American Journal of Surgical Pathology 37 1433-1440. (https://doi.org/10.1097/ PAS.0b013e31828d387b)

Duregon E, Volante M, Giorcelli J, Terzolo M, Lalli E \& Papotti M 2013b Diagnostic and prognostic role of Steroidogenic Factor-1 in adrenocortical carcinoma: a validation study focusing on clinical and pathological correlates. Human Pathology 44 822-828. (https://doi. org/10.1016/j.humpath.2012.07.025)

Duregon E, Molinaro L, Volante M, Ventura L, Righi L, Bolla S, Terzolo M, Sapino A \& Papotti MG 2014a Comparative diagnostic and prognostic performances of the hematoxylin-eosin and phospho-histone $\mathrm{H} 3$ mitotic count and Ki-67 index in adrenocortical carcinoma. Modern Pathology 27 1246-1254. (https://doi.org/10.1038/ modpathol.2013.230)

Duregon E, Rapa I, Votta A, Giorcelli J, Daffara F, Terzolo M, Scagliotti GV, Volante M \& Papotti M 2014b MicroRNA expression patterns in adrenocortical carcinoma variants and clinical pathologic correlations. Human Pathology 45 1555-1562. (https://doi. org/10.1016/j.humpath.2014.04.005)

Duregon E, Volante M, Rapa I, Vatrano S \& Papotti M 2015 Dissecting morphological and molecular heterogeneity in adrenocortical carcinoma. Turkish Journal of Pathology 31 (Supplement 1) 98-104. (https://doi.org/10.5146/tjpath.2015.01317)

Duregon E, Cappellesso R, Maffeis V, Zaggia B, Ventura L, Berruti A, Terzolo M, Fassina A, Volante M \& Papotti M 2017 Validation of the prognostic role of the 'Helsinki Score' in 225 cases of adrenocortical carcinoma. Human Pathology 62 1-7. (https://doi.org/10.1016/j. humpath.2016.09.035)

Ekström EJ, Bergenfelz C, von Bülow V, Serifler F, Carlemalm E, Jönsson G, Andersson T \& Leandersson K 2014 WNT5A induces release of exosomes containing pro-angiogenic and immunosuppressive factors from malignant melanoma cells. Molecular Cancer 13 88. (https://doi.org/10.1186/1476-4598-13-88)

Else T 2011 Overview of genetic syndromes associated with adrenociortical cancer. In Adrenocortical Carcinoma. Basic Science and Clinical Concepts, pp 153-172. Eds GD Hammer \& T Else. New York, NY, USA: Springer Science+Business Media. (https://doi. org/10.1007/978-0-387-77236-3)

Else T, Kim A, Sabolch A, Raymond V, Kandathil A, Caoili E, Shruti J, Miller BS, Giordano TJ \& Hammer GD 2014 Adrenocortical carcinoma. Endocrine Reviews 35 282-326. (https://doi.org/10.1210/ er.2013-1029)

El Wakil A \& Lalli E 2011 The Wnt/beta-catenin pathway in adrenocortical development and cancer. Molecular and Cellular Endocrinology 332 32-37. (https://doi.org/10.1016/j.mce.2010.11.014)

Fassnacht M, Terzolo M, Allolio B, Baudin E, Haak H, Berruti A, Welin S, Schade-Brittinger C, Lacroix A, Jarzab B, et al. 2012 Combination chemotherapy in advanced adrenocortical carcinoma. New England Journal of Medicine 366 2189-2197. (https://doi.org/10.1056/ NEJMoa1200966)

Fassnacht M, Berruti A, Baudin E, Demeure MJ, Gilbert J, Haak H, Kroiss M, Quinn DI, Hesseltine E, Ronchi CL, et al. 2015 Linsitinib (OSI-906) versus placebo for patients with locally advanced or metastatic adrenocortical carcinoma: a double-blind, randomised, phase 3 study. Lancet Oncology 6 426-435. (https://doi.org/10.1016/ S1470-2045(15)70081-1)

Fenske W, Völker HU, Adam P, Hahner S, Johanssen S, Wortmann S, Schmidt M, Morcos M, Müller-Hermelink HK, Allolio B, et al. 2009 Glucose transporter GLUT1 expression is an stage-independent predictor of clinical outcome in adrenocortical carcinoma. EndocrineRelated Cancer 16 919-928. (https://doi.org/10.1677/ERC-08-0211)

Fonseca AL, Kugelberg J, Starker LF, Scholl U, Choi M, Hellman P, Akerström G, Westin G, Lifton RP, Björklund P, et al. 2012 Comprehensive DNA methylation analysis of benign and malignant adrenocortical tumors. Genes, Chromosomes and Cancer 51 949-960. (https://doi.org/10.1002/gcc.21978)

Fragoso MC, Almeida MQ, Mazzuco TL, Mariani BM, Brito LP, Gonçalves TC, Alencar GA, de Lima LO, Faria AM, Bourdeau I, et al. 2012 Combined expression of BUB1B, DLGAP5, and PINK1 as predictors of poor outcome in adrenocortical tumors: validation in a Brazilian cohort of adult and pediatric patients. European Journal of Endocrinology 66 61-67. (https://doi.org/10.1530/EJE-11-0806)

Gaujoux S, Grabar S, Fassnacht M, Ragazzon B, Launay P, Libé R, Chokri I, Audebourg A, Royer B, Sbiera S, et al. 2011 ß-Catenin activation is associated with specific clinical and pathologic characteristics and a poor outcome in adrenocortical carcinoma. Clinical Cancer Research 17 328-336. (https://doi.org/10.1158/10780432.CCR-10-2006)

Gaujoux S, Hantel C, Launay P, Bonnet S, Perlemoine K, Lefèvre L, Guillaud-Bataille M, Beuschlein F, Tissier F, Bertherat J, et al. 2013 Silencing mutated $\beta$-catenin inhibits cell proliferation and stimulates apoptosis in the adrenocortical cancer cell line H295R. PLOS ONE 8 e55743. (https://doi.org/10.1371/journal.pone.0055743)

Ghasemi R, Grassadonia A, Tinari N, Piccolo E, Natoli C, Tomao F \& Iacobelli S 2013 Tumor-derived microvesicles: the metastasomes. Medical Hypotheses 80 75-82. (https://doi.org/10.1016/j. mehy.2012.10.011)

Gerdes J, Schwab U, Lemke H \& Stein H 1983 Production of a mouse monoclonal antibody reactive with a human nuclear antigen associated with cell proliferation. International Journal of Cancer $\mathbf{3 1}$ 13-20. (https://doi.org/10.1002/ijc.2910310104)

Gicquel C, Bertagna X, Gaston V, Coste J, Louvel A, Baudin E, Bertherat J, Chapuis Y, Duclos JM, Schlumberger M, et al. 2001 Molecular markers and long-term recurrences in a large cohort of patients with sporadic adrenocortical tumors. Cancer Research $\mathbf{6 1}$ 6762-6767. 
Giordano TJ, Thomas DG, Kuick R, Lizyness M, Misek DE, Smith AL, Sanders D, Aljundi RT, Gauger PG, Thompson NW, et al. 2003 Distinct transcriptional profiles of adrenocortical tumors uncovered by DNA microarray analysis. American Journal of Pathology 162 521-531. (https://doi.org/10.1016/S0002-9440(10)63846-1)

Giordano TJ, Kuick R, Else T, Gauger PG, Vinco M, Bauersfeld J, Sanders D, Thomas DG, Doherty G \& Hammer G 2009 Molecular classification and prognostication of adrenocortical tumors by transcriptome profiling. Clinical Cancer Research 15 668-676. (https:// doi.org/10.1158/1078-0432.CCR-08-1067)

Goh G, Scholl UI, Healy JM, Choi M, Prasad ML, Nelson-Williams C, Kunstman JW, Korah R, Suttorp AC, Dietrich D, et al. 2014 Recurrent activating mutation in PRKACA in cortisol-producing adrenal tumors. Nature Genetics 46 613-617. (https://doi.org/10.1038/ ng.2956)

Hantel C \& Beuschlein F 2015 Xenograft models for adrenocortical carcinoma. Molecular and Cellular Endocrinology 421 28-33. (https:// doi.org/10.1016/j.mce.2015.05.031)

Hantel C, Shapiro I, Poli G, Chiapponi C, Bidlingmaier M, Reincke M, Luconi M, Jung S \& Beuschlein F 2016 Targeting heterogeneity of adrenocortical carcinoma: evaluation and extension of preclinical tumor models to improve clinical translation. Oncotarget 7 79292-79304. (https://doi.org/10.18632/oncotarget.12685)

Hashimoto Y, Kim DJ \& Adams JC 2011 The roles of fascins in health and disease. Journal of Pathology 224 289-300. (https://doi. org/10.1002/path.2894)

Hassan N, Zhao JT \& Sidhu SB 2017 The role of microRNAs in the pathophysiology of adrenal tumors. Molecular and Cellular Endocrinology 456 36-43. (https://doi.org/10.1016/j.mce.2016.12.011)

Heaton JH, Wood MA, Kim AC, Lima LO, Barlaskar FM, Almeida MQ, Fragoso MC, Kuick R, Lerario AM, Simon DP, et al. 2012 Progression to adrenocortical tumorigenesis in mice and humans through insulin-like growth factor 2 and $\beta$-catenin. American Journal of Pathology 181 1017-1033. (https://doi.org/10.1016/j. ajpath.2012.05.026)

Hoshino D, Kirkbride KC, Costello K, Clark ES, Sinha S, Grega-Larson N, Tyska MJ \& Weaver AM 2013 Exosome secretion is enhanced by invadopodia and drives invasive behavior. Cell Reports 5 1159-1168. (https://doi.org/10.1016/j.celrep.2013.10.050)

Hou JM, Krebs MG, Lancashire L, Sloane R, Backen A, Swain RK, Priest LJ, Greystoke A, Zhou C, Morris K, et al. 2012 Clinical significance and molecular characteristics of circulating tumor cells and circulating tumor microemboli in patients with small-cell lung cancer. Journal of Clinical Oncology 30 525-532. (https://doi. org/10.1200/JCO.2010.33.3716)

Huang FK, Han S, Xing B, Huang J, Liu B, Bordeleau F, ReinhartKing CA, Zhang JJ \& Huang XY 2015 Targeted inhibition of fascin function blocks tumour invasion and metastatic colonization. Nature Communications 6 7465. (https://doi.org/10.1038/ncomms8465)

Ignatiadis M, Lee M \& Jeffrey SS 2015 Circulating tumor cells and circulating tumor DNA: challenges and opportunities on the path to clinical utility. Clinical Cancer Research 21 4786-4800. (https://doi. org/10.1158/1078-0432.CCR-14-1190)

Jouinot A, Assie G, Libe R, Fassnacht M, Papathomas T, Barreau O, de la Villeon B, Faillot S, Hamzaoui N, Neou M, et al. 2017 DNA methylation is an independent prognostic marker of survival in adrenocortical cancer. Journal of Clinical Endocrinology and Metabolism 102 923-932. (https://doi.org/10.1210/jc.2016-3205)

Juhlin CC, Goh G, Healy JM, Fonseca AL, Scholl UI, Stenman A, Kunstman JW, Brown TC, Overton JD, Mane SM, et al. 2015 Wholeexome sequencing characterizes the landscape of somatic mutations and copy number alterations in adrenocortical carcinoma. Journal of Clinical Endocrinology and Metabolism 100 E493-E502. (https://doi. org/10.1210/jc.2014-3282)

Khoo BL, Grenci G, Jing T, Lim YB, Lee SC, Thiery JP, Han J \& Lim CT 2016 Liquid biopsy and therapeutic response: circulating tumor cell cultures for evaluation of anticancer treatment. Science Advances 2 e1600274. (https://doi.org/10.1126/sciadv.1600274)

Khorram-Manesh A, Ahlman H, Jansson S \& Nilsson O 2002 N-cadherin expression in adrenal tumors: upregulation in malignant pheochromocytoma and downregulation in adrenocortical carcinoma. Endocrine Pathology 13 99-110. (https://doi.org/10.1385/ EP:13:2:099)

Kjellin H, Johansson H, Höög A, Lehtiö J, Jakobsson PJ \& Kjellman M 2014 Differentially expressed proteins in malignant and benign adrenocortical tumors. PLOS ONE 9 e87951. (https://doi.org/10.1371/ journal.pone.0087951)

Lalli E 2010 Adrenocortical development and cancer: focus on SF-1. Journal of Molecular Endocrinology 44 301-307. (https://doi. org/10.1677/JME-09-0143)

Lalli E \& Figueiredo BC 2015 Pediatric adrenocortical tumors: what they can tell us on adrenal development and comparison with adult adrenal tumors. Frontiers in Endocrinology 6 23. (https://doi. org/10.3389/fendo.2015.00023)

Lambert AW, Pattabiraman DR \& Weinberg RA 2017 Emerging biological principles of metastasis. Cell 168 670-691. (https://doi.org/10.1016/j. cell.2016.11.037)

Leccia F, Batisse-Lignier M, Sahut-Barnola I, Val P, LefrançoisMartinez AM \& Martinez A 2016 Mouse models recapitulating human adrenocortical tumors: what is lacking? Frontiers in Endocrinology 7 93. (https://doi.org/10.3389/fendo.2016.00093)

Liao TT \& Yang MH 2017 Revisiting epithelial-mesenchymal transition in cancer metastasis: the connection between epithelial plasticity and stemness. Molecular Oncology 11 792-804. (https://doi. org/10.1002/1878-0261.12096)

Lima CR, Gomes CC \& Santos MF 2017 Role of microRNAs in endocrine cancer metastasis. Molecular and Cellular Endocrinology 456 62-75. (https://doi.org/10.1016/j.mce.2017.03.015)

Logié A, Boudou P, Boccon-Gibod L, Baudin E, Vassal G, Schlumberger M, Le Bouc Y \& Gicquel C 2000 Establishment and characterization of a human adrenocortical carcinoma xenograft model. Endocrinology 141 3165-3171. (https://doi.org/10.1210/ endo.141.9.7668)

Luconi M \& Mannelli M 2012 Xenograft models for preclinical drug testing: implications for adrenocortical cancer. Molecular and Cellular Endocrinology 351 71-77. (https://doi.org/10.1016/j.mce.2011.09.043)

Luzzi KJ, MacDonald IC, Schmidt EE, Kerkvliet N, Morris VL, Chambers AF \& Groom AC 1998 Multistep nature of metastatic inefficiency: dormancy of solitary cells after successful extravasation and limited survival of early micrometastases. American Journal of Pathology 153 865-873. (https://doi.org/10.1016/S00029440(10)65628-3)

Magro G, Esposito G, Cecchetto G, Dall'Igna P, Marcato R, Gambini C, Boldrini R, Collini P, D'Onofrio V, Salfi N, et al. 2012 Pediatric adrenocortical tumors: morphological diagnostic criteria and immunohistochemical expression of matrix metalloproteinase type 2 and human leucocyte-associated antigen (HLA) class II antigens. Results from the Italian Pediatric Rare Tumor (TREP) Study project. Human Pathology 43 31-39. (https://doi.org/10.1016/ j.humpath.2011.04.016)

McNicol AM, Struthers AL, Nolan CE, Hermans J \& Haak HR 1997 Proliferation in adrenocortical tumors: correlation with clinical outcome and p53 status. Endocrine Pathology 8 29-36. (https://doi. org/10.1007/BF02739705)

Michalkiewicz E, Sandrini R, Figueiredo B, Miranda EC, Caran E, Oliveira-Filho AG, Marques R, Pianovski MA, Lacerda L, Cristofani LM, et al. 2004 Clinical and outcome characteristics of children with adrenocortical tumors: a report from the International Pediatric Adrenocortical Tumor Registry. Journal of Clinical Oncology 22 838-845. (https://doi.org/10.1200/JCO.2004.08.085)

Milane L, Singh A, Mattheolabakis G, Suresh M \& Amiji MM 2015 Exosome mediated communication within the tumor 
microenvironment. Journal of Controlled Release 219 278-294 (https://doi.org/10.1016/j.jconrel.2015.06.029)

Mocellin S, Hoon D, Ambrosi A, Nitti D \& Rossi CR 2006 The prognostic value of circulating tumor cells in patients with melanoma: a systematic review and meta-analysis. Clinical Cancer Research 12 4605-4613. (https://doi.org/10.1158/10780432.CCR-06-0823)

Morimoto R, Satoh F, Murakami O, Suzuki T, Abe T, Tanemoto M, Abe M, Uruno A, Ishidoya S, Arai Y, et al. 2008 Immunohistochemistry of a proliferation marker Ki67/MIB1 in adrenocortical carcinomas: Ki67/MIB1 labeling index is a predictor for recurrence of adrenocortical carcinomas. Endocrine Journal $\mathbf{5 5}$ 49-55. (https://doi.org/10.1507/endocrj.K07-079)

Morin A, Ruggiero C, Robidel E, Doghman-Bouguerra M, Das AT, Castellano R, Josselin E, Favier J \& Lalli E 2017 Establishment of a mouse xenograft model of metastatic adrenocortical carcinoma. Oncotarget 8 51050-51057. (https://doi.org/10.18632/ oncotarget.16909)

Mu W, Rana S \& Zöller M 2013 Host matrix modulation by tumor exosomes promotes motility and invasiveness. Neoplasia 15 875-887. (https://doi.org/10.1593/neo.13786)

Nieto MA, Huang RY, Jackson RA \& Thiery JP 2016 EMT: 2016. Cell 66 21-45. (https://doi.org/10.1016/j.cell.2016.06.028)

Papathomas TG, Pucci E, Giordano TJ, Lu H, Duregon E, Volante M, Papotti M, Lloyd RV, Tischler AS, van Nederveen FH, et al. 2016 An international Ki67 reproducibility study in adrenal cortical carcinoma. American Journal of Surgical Pathology 40 569-576. (https://doi.org/10.1097/PAS.0000000000000574)

Papotti M, Libé R, Duregon E, Volante M, Bertherat J \& Tissier F 2011 The Weiss score and beyond - histopathology for adrenocortical carcinoma. Hormones and Cancer 2 333-340. (https://doi.org/10.1007/ s12672-011-0088-0)

Patel D, Boufraqech M, Jain M, Zhang L, He M, Gesuwan K, Gulati N, Nilubol N, Fojo T \& Kebebew E 2013 MiR-34a and miR-483-5p are candidate serum biomarkers for adrenocortical tumors. Surgery $\mathbf{1 5 4}$ 1224-1228. (https://doi.org/10.1016/j.surg.2013.06.022)

Patterson EE, Holloway AK, Weng J, Fojo T \& Kebebew E 2011 MicroRNA profiling of adrenocortical tumors reveals miR-483 as a marker of malignancy. Cancer 117 1630-1639. (https://doi. org/10.1002/cncr.25724)

Pennanen M, Heiskanen I, Sane T, Remes S, Mustonen H, Haglund C \& Arola J 2015 Helsinki score - a novel model for prediction of metastases in adrenocortical carcinomas. Human Pathology 46 404-410. (https://doi.org/10.1016/j.humpath.2014.11.015)

Perdigones N \& Murtaza M 2017 Capturing tumor heterogeneity and clonal evolution in solid cancers using circulating tumor DNA analysis. Pharmacology and Therapeutics 174 22-26. (https://doi org/10.1016/j.pharmthera.2017.02.003)

Perge P, Butz H, Pezzani R, Bancos I, Nagy Z, Pálóczi K, Nyírô G, Decmann Á, Pap E, Luconi M, et al. 2017 Evaluation and diagnostic potential of circulating extracellular vesicle-associated microRNAs in adrenocortical tumors. Scientific Reports 7 5474. (https://doi. org/10.1038/s41598-017-05777-0)

Pinheiro C, Granja S, Longatto-Filho A, Faria AM, Fragoso MC Lovisolo SM, Lerário AM, Almeida MQ, Baltazar F \& Zerbini MC 2015 Metabolic reprogramming: a new relevant pathway in adult adrenocortical tumors. Oncotarget 6 44403-44421. (https://doi. org/10.18632/oncotarget.5623)

Pinto EM, Morton C, Rodriguez-Galindo C, McGregor L, Davidoff AM, Mercer K, Debelenko LV, Billups C, Ribeiro RC \& Zambetti GP 2013 Establishment and characterization of the first pediatric adrenocortical carcinoma xenograft model identifies topotecan as a potential chemotherapeutic agent. Clinical Cancer Research 19 1740-1747. (https://doi.org/10.1158/1078-0432.CCR-12-3354)

Pinto EM, Chen X, Easton J, Finkelstein D, Liu Z, Pounds S, RodriguezGalindo C, Lund TC, Mardis ER, Wilson RK, et al. 2015 Genomic landscape of paediatric adrenocortical tumours. Nature Communications 6 6302. (https://doi.org/10.1038/ncomms7302)

Pinto EM, Rodriguez-Galindo C, Choi JK, Pounds S, Liu Z, Neale G, Finkelstein D, Hicks JM, Pappo AS, Figueiredo BC, et al. 2016 Prognostic significance of major histocompatibility complex class II expression in pediatric adrenocortical tumors: a St. Jude and Children's Oncology Group Study. Clinical Cancer Research 22 6247-6255. (https://doi.org/10.1158/1078-0432.CCR-15-2738)

Pinto EM, Rodriguez-Galindo C, Pounds SB, Wang L, Clay MR, Neale G, Garfinkle EAR, Lam CG, Levy CF, Pappo AS, et al. 2017 Identification of clinical and biologic correlates associated with outcome in children with adrenocortical tumors without germline TP53 mutations: a St. Jude Adrenocortical Tumor Registry and Children's Oncology Group study. Journal of Clinical Oncology [epub]. (https:// doi.org/10.1200/JCO.2017.74.2460)

Pinzani P, Scatena C, Salvianti F, Corsini E, Canu L, Poli G, Paglierani M, Piccini V, Pazzagli M, Nesi G, et al. 2013 Detection of circulating tumor cells in patients with adrenocortical carcinoma: a monocentric preliminary study. Journal of Clinical Endocrinology and Metabolism 98 3731-3738. (https://doi.org/10.1210/jc.2013-1396)

Poli G, Ceni E, Armignacco R, Ercolino T, Canu L, Baroni G, Nesi G, Galli A, Mannelli M \& Luconi M 2015 2D-DIGE proteomic analysis identifies new potential therapeutic targets for adrenocortical carcinoma. Oncotarget 6 5695-5706. (https://doi.org/10.18632/ oncotarget.3299)

Poli G, Cantini G, Armignacco R, Fucci R, Santi R, Canu L, Nesi G, Mannelli M \& Luconi M 2016 Metformin as a new anti-cancer drug in adrenocortical carcinoma. Oncotarget 7 49636-49648. (https://doi. org/10.18632/oncotarget.10421)

Ragazzon B, Libé R, Gaujoux S, Assié G, Fratticci A, Launay P, Clauser E, Bertagna X, Tissier F, de Reyniès A, et al. 2010 Transcriptome analysis reveals that p53 and beta-catenin alterations occur in a group of aggressive adrenocortical cancers. Cancer Research 70 8276-8281. (https://doi.org/10.1158/0008-5472.CAN-10-2014)

Rahbari NN, Aigner M, Thorlund K, Mollberg N, Motschall E, Jensen K, Diener MK, Büchler MW, Koch M \& Weitz J 2010 Meta-analysis shows that detection of circulating tumor cells indicates poor prognosis in patients with colorectal cancer. Gastroenterology 138 1714-1726. (https://doi.org/10.1053/j.gastro.2010.01.008)

Rechache NS, Wang Y, Stevenson HS, Killian JK, Edelman DC, Merino M, Zhang L, Nilubol N, Stratakis CA, Meltzer PS, et al. 2012 DNA methylation profiling identifies global methylation differences and markers of adrenocortical tumors. Journal of Clinical Endocrinology and Metabolism 97 1004-1013. (https://doi. org/10.1210/jc.2011-3298)

Roca E, Berruti A, Sbiera S, Rapa I, Oneda E, Sperone P, Ronchi CL, Ferrari L, Grisanti S, Germano A, et al. 2017 Topoisomerase $2 \alpha$ and thymidylate synthase expression in adrenocortical cancer. EndocrineRelated Cancer 24 299-307. (https://doi.org/10.1530/ERC-17-0095)

Ronchi CL, Sbiera S, Kraus L, Wortmann S, Johanssen S, Adam P, Willenberg HS, Hahner S, Allolio B \& Fassnacht M 2009 Expression of excision repair cross complementing group 1 and prognosis in adrenocortical carcinoma patients treated with platinum-based chemotherapy. Endocrine-Related Cancer 16 907-918. (https://doi. org/10.1677/ERC-08-0224)

Ronchi CL, Sbiera S, Leich E, Tissier F, Steinhauer S, Deutschbein T, Fassnacht M \& Allolio B 2012 Low SGK1 expression in human adrenocortical tumors is associated with ACTH-independent glucocorticoid secretion and poor prognosis. Journal of Clinical Endocrinology and Metabolism 97 E2251-E2260. (https://doi. org/10.1210/jc.2012-2669)

Ronchi CL, Sbiera S, Leich E, Henzel K, Rosenwald A, Allolio B, Fassnacht M 2013 Single nucleotide polymorphism array profiling of adrenocortical tumors - evidence for an adenoma carcinoma sequence? PLOS ONE 8 e73959. (https://doi.org/10.1371/journal. pone.0073959) 
Ronchi CL, Sbiera S, Altieri B, Steinhauer S, Wild V, Bekteshi M, Kroiss M, Fassnacht M \& Allolio B 2015 Notch1 pathway in adrenocortical carcinomas: correlations with clinical outcome. Endocrine-Related Cancer 22 531-543. (https://doi.org/10.1530/ERC15-0163)

Rosati R, Cerrato F, Doghman M, Pianovski MAD, Parise GA, Custódio G, Zambetti GP, Ribeiro RC, Riccio A, Figueiredo BC, et al. 2008 High frequency of loss of heterozygosity at 11p15 and IGF2 overexpression is not associated with clinical outcome in childhood adrenocortical tumors positive for the R337H TP53 mutation. Cancer Genetics and Cytogenetics 186 19-24. (https://doi.org/10.1016/j. cancergencyto.2008.05.010)

Ruggiero C, Doghman-Bouguerra M, Sbiera S, Sbiera I, Parsons M, Ragazzon B, Morin A, Robidel R, Favier J \& Bertherat J 2017 Dosagedependent regulation of VAV2 expression by Steroidogenic Factor-1 drives adrenocortical carcinoma cell invasion. Science Signaling 10 eaal2464. (https://doi.org/10.1126/scisignal.aal2464)

Salomon A, Keramidas M, Maisin C \& Thomas M 2015 Loss of $\beta$-catenin in adrenocortical cancer cells causes growth inhibition and reversal of epithelial-to-mesenchymal transition. Oncotarget 6 11421-11433. (https://doi.org/10.18632/oncotarget.3222)

Salvianti F \& Pinzani P 2017 The diagnostic potential of mutation detection from single circulating tumor cells in cancer patients. Expert Review of Molecular Diagnostics 22 1-7. (https://doi. org/10.18632/oncotarget.19118)

Salvianti F, Canu L, Poli G, Armignacco R, Scatena C, Cantini G, Di Franco A, Gelmini S, Ercolino T, Pazzagli M, et al. 2017 New insights in the clinical and translational relevance of miR483-5p in adrenocortical cancer. Oncotarget 8 65525-65533. (https://doi.org/10. 1080/14737159.2017.1381561)

Sato Y, Maekawa S, Ishii R, Sanada M, Morikawa T, Shiraishi Y, Yoshida K, Nagata Y, Sato-Otsubo A, Yoshizato T, et al. 2014 Recurrent somatic mutations underlie corticotropin-independent Cushing's syndrome. Science 344 917-920. (https://doi.org/10.1126/ science.1252328)

Sbiera S, Schmull S, Assie G, Voelker HU, Kraus L, Beyer M, Ragazzon B, Beuschlein F, Willenberg HS, Hahner S, et al. 2010 High diagnostic and prognostic value of Steroidogenic Factor-1 expression in adrenal tumors. Journal of Clinical Endocrinology and Metabolism 95 E161-E171. (https://doi.org/10.1210/jc.2010-0653)

Sbiera S, Sbiera I, Ruggiero C, Doghman-Bouguerra M, Korpershoek E, de Krijger RR, Haak H, Volante M, Papotti M, Reimondo G, et al. 2017 Assessment of VAV2 expression refines prognostic prediction in adrenocortical carcinoma. Journal of Clinical Endocrinology and Metabolism 102 3491-3498. (https://doi.org/10.1210/jc.2017-00984)

Simon DP, Giordano TJ \& Hammer GD 2012 Upregulated JAG1 enhances cell proliferation in adrenocortical carcinoma. Clinical Cancer Research 18 2452-2464. (https://doi.org/10.1158/1078-0432. CCR-11-2371)

Siravegna G, Marsoni S, Siena S \& Bardelli A 2017 Integrating liquid biopsies into the management of cancer. Nature Reviews Clinical Oncology 14 531-548. (https://doi.org/10.1038/nrclinonc.2017.14)

Soon PS, Tacon LJ, Gill AJ, Bambach CP, Sywak MS, Campbell PR, Yeh MW, Wong SG, Clifton-Bligh RJ, Robinson BG, et al. 2009 miR195 and miR-483-5p identified as predictors of poor prognosis in adrenocortical cancer. Clinical Cancer Research 15 7684-7692. (https://doi.org/10.1158/1078-0432.CCR-09-1587)

Suchorska WM \& Lach MS 2016 The role of exosomes in tumor progression and metastasis. Oncology Reports 35 1237-1244. (https:// doi.org/10.3892/or.2015.4507)

Szabó DR, Luconi M, Szabó PM, Tóth M, Szücs N, Horányi J, Nagy Z, Mannelli M, Patócs A, Rácz K, et al. 2014 Analysis of circulating microRNAs in adrenocortical tumors. Laboratory Investigation 94 331-339. (https://doi.org/10.1038/labinvest.2013.148)

Terzolo M, Boccuzzi A, Bovio S, Cappia S, De Giuli P, Alì A, Paccotti P, Porpiglia F, Fontana D \& Angeli A 2001 Immunohistochemical assessment of Ki-67 in the differential diagnosis of adrenocortical tumors. Urology 57 176-182. (https://doi.org/10.1016/S00904295(00)00852-9)

Terzolo M, Angeli A, Fassnacht M, Daffara F, Tauchmanova L, Conton PA, Rossetto R, Buci L, Sperone P, Grossrubatscher E, et al. 2007 Adjuvant mitotane treatment for adrenocortical carcinoma. New England Journal of Medicine 356 2372-2380. (https://doi. org/10.1056/NEJMoa063360)

Tissier F, Louvel A, Grabar S, Hagnéré AM, Bertherat J, VacherLavenu MC, Dousset B, Chapuis Y, Bertagna X \& Gicquel C 2004 Cyclin E correlates with malignancy and adverse prognosis in adrenocortical tumors. European Journal of Endocrinology $\mathbf{1 5 0}$ 809-817. (https://doi.org/10.1530/eje.0.1500809)

Tissier F, Cavard C, Groussin L, Perlemoine K, Fumey G, Hagneré AM, René-Corail F, Jullian E, Gicquel C, Bertagna X, et al. 2005 Mutations of beta-catenin in adrenocortical tumors: activation of the Wnt signaling pathway is a frequent event in both benign and malignant adrenocortical tumors. Cancer Research 65 7622-7627. (https://doi. org/10.1158/0008-5472.CAN-05-0593)

Valastyan S \& Weinberg RA 2011 Tumor metastasis: molecular insights and evolving paradigms. Cell 147 275-292. (https://doi. org/10.1016/j.cell.2011.09.024)

Vanharanta S \& Massagué J 2013 Origin of metastatic traits. Cancer Cell 24 410-421. (https://doi.org/10.1016/j.ccr.2013.09.007)

Volante M, Sperone P, Bollito E, Frangipane E, Rosas R, Daffara F, Terzolo M, Berruti A \& Papotti M 2006 Matrix metalloproteinase type 2 expression in malignant adrenocortical tumors: diagnostic and prognostic significance in a series of 50 adrenocortical carcinomas. Modern Pathology 19 1563-1569. (https://doi. org/10.1038/modpathol.3800683)

Volante M, Bollito E, Sperone P, Tavaglione V, Daffara F, Porpiglia F, Terzolo M, Berruti A \& Papotti M 2009 Clinicopathological study of a series of 92 adrenocortical carcinomas: from a proposal of simplified diagnostic algorithm to prognostic stratification. Histopathology 55 535-543. (https://doi org/10.1111/j.1365-2559.2009.03423.x)

Volante M, Terzolo M, Fassnacht M, Rapa I, Germano A, Sbiera S, Daffara F, Sperone P, Scagliotti G, Allolio B, et al. 2012 Ribonucleotide reductase large subunit (RRM1) gene expression may predict efficacy of adjuvant mitotane in adrenocortical cancer. Clinical Cancer Research 18 3452-3461. (https://doi. org/10.1158/1078-0432.CCR-11-2692)

Wang H, Stoecklein NH, Lin PP \& Gires O 2017 Circulating and disseminated tumor cells: diagnostic tools and therapeutic targets in motion. Oncotarget 8 1884-1912. (https://doi.org/10.18632/ oncotarget.12242)

Weiss LM 1984 Comparative histologic study of 43 metastasizing and nonmetastasizing adrenocortical tumors. American Journal of Surgical Pathology 8 163-169. (https://doi.org/10.1097/00000478-19840300000001)

Went PT, Lugli A, Meier S, Bundi M, Mirlacher M, Sauter G \& Dirnhofer S 2004 Frequent EpCAM protein expression in human carcinomas. Human Pathology 35 122-128. (https://doi.org/10.1016/j. humpath.2003.08.026)

West AN, Neale GA, Pounds S, Figueredo BC, Rodriguez Galindo C, Pianovski MA, Oliveira Filho AG, Malkin D, Lalli E, Ribeiro R, et al. 2007 Gene expression profiling of childhood adrenocortical tumors. Cancer Research 67 600-608. (https://doi.org/10.1158/0008-5472. CAN-06-3767)

Wiedswang G, Borgen E, Schirmer C, Kåresen R, Kvalheim G, Nesland JM \& Naume B 2006 Comparison of the clinical significance of occult tumor cells in blood and bone marrow in breast cancer. International Journal of Cancer 118 2013-2019. (https://doi. org/10.1002/ijc.21576)

Wieneke JA, Thompson LD \& Heffess CS 2003 Adrenal cortical neoplasms in the pediatric population: a clinicopathologic and 
immunophenotypic analysis of 83 patients. American Journal of Surgical Pathology 27 867-881. (https://doi.org/10.1097/00000478200307000-00001)

Yang MS, Wang HS, Wang BS, Li WH, Pang ZF, Zou BK, Zhang X, Shi XT, Mu DB, Zhang DX, et al. 2013 A comparative proteomic study identified calreticulin and prohibitin up-regulated in adrenocortical carcinomas. Diagnostic Pathology 8 58. (https://doi. org/10.1186/1746-1596-8-58)

Yu M, Bardia A, Aceto N, Bersani F, Madden MW, Donaldson MC, Desai R, Zhu H, Comaills V, Zheng Z, et al. 2014 Cancer therapy. Ex vivo culture of circulating breast tumor cells for individualized testing of drug susceptibility. Science 345 216-220. (https://doi. org/10.1126/science.1253533)

Zhang L, Riethdorf S, Wu G, Wang T, Yang K, Peng G, Liu J \& Pantel K 2012 Meta-analysis of the prognostic value of circulating tumor cells in breast cancer. Clinical Cancer Research 18 5701-5710. (https://doi. org/10.1158/1078-0432.CCR-12-1587)

Zheng S, Cherniack AD, Dewal N, Moffitt RA, Danilova L, Murray BA, Lerario AM, Else T, Knijnenburg TA, Ciriello G, et al. 2016 Comprehensive pan-genomic characterization of adrenocortical carcinoma. Cancer Cell 29 723-736. (https://doi.org/10.1016/j. ccell.2016.04.002)

Received in final form 13 November 2017

Accepted 15 November 2017

Accepted preprint published online 15 November 2017 